\title{
Phytoplankton Response to Changes in Water Quality and a Flood Event in Hervey Bay, Queensland
}

\author{
Deborah P. Milham-Scott ${ }^{1,2}$ \\ ${ }^{1}$ Independent Researcher, Alexandra Headland, QLD 4572 Australia \\ ${ }^{2}$ Department of Chemical Engineering and Centre for Microscopy and Microanalysis, University of Queensland (formally of: affiliation for research), \\ Brisbane, QLD 4072 Australia \\ Corresponding author: Deborah P. Milham-Scott (dmilham12@gmail.com)
}

This research was funded by the Hervey Bay City Council and the Department of Chemical Engineering at the University of Queensland

ABSTRACT Dynamic, integrated and complex processes dominate nearshore marine ecosystems. Industrial, agricultural and population growth delivers pollution and excess nutrient and sediment loads to nearshore marine zones. Climate change also poses serious threats to the delicate balance that exists between and within marine ecosystem processes. Methods to monitor, characterise and model nearshore marine systems have been developed to predict responses to changes in the physical, chemical and biological parameters that constitute elements of a model. Such models are useful to management authorities as they provide a tool to mitigate adverse impacts to marine ecosystems. Phytoplankton community structure provides a sensitive early warning for change to marine ecosystems. It is also a vital component of models derived to determine light attenuation and requirements for healthy seagrass and coral habitats. The multifactorial physicochemical drivers of change to marine microalgae abundance and community structure were investigated in Hervey Bay following two floods, a cyclone and destruction of $1000 \mathrm{~km}^{2}$ of seagrass. A water quality gradient from point sources to offshore sites was identified. Correlations between chlorophyll $a(\mathrm{Chl} a)$ and both soluble reactive phosphate (SRP) and total suspended solids was revealed. Diatoms dominated the phytoplankton community structure with seasonal and site differences detected amongst 150 phytoplankton species. Chl $a$, Secchi depth, SRP and pH maximised the rank correlation with phytoplankton assemblage structure $(\rho=0.63)$ to best 'explain' the link between water quality and phytoplankton (BIOENV). Indicator species include Cylindrotheca closterium for the nearshore degraded sites and Rhizosolenia sp. and Guinardia sp. (G. flaccida and G. striatula) for the offshore more pristine habitats. Following the flood in February 1995, Cylindrotheca closterium, Pseudonitzschia sp. and Skeletonema costatum bloomed at Pulgul Creek (a treated sewage effluent site), and Thalassionema frauenfeldii, Cerataulina bicornis and dinoflagellates bloomed at the mouth of the Mary River (agricultural runoff). Discharge-driven flood impact and trigger values were analysed to assist management authorities in their decision making around potential seafood biotoxin problems associated with harmful algal blooms (HAB's). Results highlight the importance of species determination rather than $\mathrm{Chl} a$ assessment when evaluating the health of an ecosystem. Spring blooms of Trichodesium sp. indicate an additional nutrient source during high traffic of commercial whale watching vessels. Flood impacts highlight the need to schedule dredging, construction and other land management and development activities outside of flood periods. Commercial fishing and swimming should be avoided following a flood due to the health risks associated with toxic phytoplankton species (HAB's) and for the health and safety of swimmers, consumers and other aquatic species. Future research to replicate this study in Hervey Bay and in other estuaries holds much value to further explore the phytoplankton species identified as bio-indicators of ecosystem health in the present study. Research yet to be published, addresses the links between water quality and seagrass epiphytes, light attenuation and the habitat requirements of seagrass in Hervey Bay.

INDEX TERMS Biodiversity, chlorophyll $a(\mathrm{Chl} a)$, eutrophication, Hervey Bay, phytoplankton, water quality, seagrass 


\section{INTRODUCTION}

\subsection{GENERAL OVERVIEW}

Baseline water quality data is fundamental to understanding the influence of coastal processes on the health of nearshore marine systems. The lack of knowledge on the biota that support maritime, recreational and commercial activity in Hervey Bay is a concern that prompted biodiversity surveys but not exploration of the processes that underpin biodiversity in the region. Phytoplankton mediates atmospheric and aquatic processes in marine and freshwater ecosystems by sequestering atmospheric carbon dioxide $\left(\mathrm{CO}_{2}\right)$ to become a food source itself. Anthropogenic activity and excess nutrient input into estuaries and nearshore zones, promotes coastal eutrophication. Offshore activities such as overfishing, influence nutrient cycling which in turn, results in decreased oceanic phytoplankton. These changes signal phytoplankton redistribution in response to anthropogenic activity $[12,14]$. Identification of eutrophication precursors and phytoplankton species that indicate habitat health is paramount. This study investigates links between water quality parameters and phytoplankton community structure to identify the drivers of ecological change within these systems and models the phytoplankton community response to multifactorial physicochemical water quality parameters (see section 1.4 for specific and more detailed study aims). Changes in phytoplankton communities provide a sensitive early warning for climatedriven change. Links to catchment activity and climate change are investigated throughout the study.

\subsection{ECOSYSTEM AND ECONOMY}

The human and ecological value of near and offshore coastal zones is related to our knowledge, perception and understanding of the diversity and ecology of the marine life that resides in these areas. The local economy of many coastal areas is based on tourism, recreational activities and fishing industries that rely either directly or indirectly on the health and ecological balance of marine environments. When change in water quality and/or biodiversity occur as a result of catchment practises or natural phenomena, adverse effects may occur that upset the balance of marine ecosystems, which in turn affect the local economy.

An example of ecosystem imbalance occurred in Hervey Bay in 1992 when the environmental health suffered significantly as a consequence of flooding from the Mary and Burrum Rivers, followed three weeks later by cyclone Fran. The major impacts came as a consequence of high energy waves, swells and currents with the potential to uproot or bury seagrass, and storm water runoff reducing salinity and increasing both turbidity and nutrient loads [1]. In addition, output from a damaged sewage treatment plant on the Mary River resulted in 1.05 ML of untreated effluent per day being discharged into the river for twelve days. In the following months, Hervey Bay experienced the loss of more than $1,000 \mathrm{~km}^{2}$ of seagrass meadows and the displacement, and some mortality, of an estimated 1,650 dugongs [1]. The damage to the seagrass, that also functions as a nursery ground for juvenile fish and prawns, was subsequently reflected in the low commercial fish catches.

\subsection{NUTRIENTS, EUTROPHICATION AND HARMFUL ALGAL BLOOMS (HAB'S)}

Estuarine environments are ranked among Australia's most valuable natural resources for the importance of their ecological processes and economic opportunity [2]. The most conspicuous effects of increased runoff as a result of human activity includes floods [3] and waste water discharge, increased turbidity, nutrient inputs and eutrophication [4,5], phytoplankton blooms [6] and increased epiphytic algal populations which may alter marine community structure and biodiversity [7] and reduce light availability in the water column required by seagrass, coral and other benthic organisms.

Eutrophication is a national and international problem that can lead to (HAB's), shellfish contamination, fish kills and prolonged closures of fisheries and aquaculture operations. The impacts affect human health directly by causing skin rashes [13] and indirectly by causing Ciguatera poisoning via the food supply [36]. Blooms may significantly decrease light penetration to benthic communities through enhanced turbidity as well as promoting growth of algal epiphytes on seagrass, coral and other sub-aquatic vegetation and substrates [8].

During the past four decades human health effects, economic consequences and biodiversity impacts of HAB's have increased in frequency, intensity and geographical distribution [9]. Many events have been documented which cause mortality in a wide range of marine biota, including valuable commercial fishery and ecotourism species [10]. Coral reefs also are negatively impacted at a distance as a consequence of nutrient enrichment in the coastal zone that increases phytoplankton concentration and stress to coral reef systems [11]. Globally however, with consideration given to open ocean, phytoplankton concentration has declined over the past century [12].

Nutrient enrichment and eutrophication stimulate the growth of phytoplankton and epiphytic algae to reduce the light available to benthic organisms [13]. Nutrients derived from fertiliser or sewage promote the growth of different phytoplankton species [14]. When light attenuation changes significantly, the effects cascade throughout an ecosystem [15] and affect the survival and growth of coral reefs, seagrass, juvenile fish and prawns and other benthic organisms [16]. Threatened and endangered species such as dugongs, dolphins, humpback whales and turtles are coastal inhabitants that rely on the healthy waterways of Hervey Bay. Recreational and commercial fishing activities, linked to a growing tourism industry, are also affected by estuarine, coastal marine and offshore marine dynamics, as 
is the recreational diving industry which makes use of similar areas.

Local community, industry and councils rely on many marine habitats. The interrelationships between local economy and ecology affect the balance and health of the marine ecosystem and understanding them is vital to their effective management and sustainable human use. Monitoring water quality is required to first, establish baseline levels for key parameters, second, to detect changes in physical, chemical and biological data that may be used as indicators in a particular ecosystem and third, to develop models as a tool for management authorities to use to balance complex marine ecosystem processes. Baseline water quality data is also fundamental to understanding the influence of coastal processes on the health of near-shore marine systems and to detect potential effects of climate change.

\subsection{POLLUTION AND HARMFUL ALGAL BLOOMS IN HERVEY BAY}

Hervey Bay lies on a latitude that borders sub-tropical and temperate zones. While Hervey Bay promotes great diversity among plant/algae and animal groups, it is a zone that has been the focus of little research, given the predominant interest of the hard coral areas of the tropics [17] and the macro algae dominated communities of temperate areas [18]. Nevertheless, this intermediate zone supports a growing tourism industry with several fishing charters, a multimillion-dollar whale watching industry, an artificial reef and a marine park.

The environmental study of Eli Creek in 1987 and 1988 [19] revealed E. coli levels greater than 800 organisms $/ \mathrm{mL}$ up to $2.0 \mathrm{~km}$ from the creek mouth (levels that 'almost guarantee the presence of dangerous pathogenic bacteria'); sediments and bottom water tainted with a 'wastewater' odour; phosphorous levels that exceed the criteria recommended by the Australian Environment Council in 1987 of $0.5 \mu \mathrm{g} / \mathrm{L}$ of total phosphorous, for the recreational use of a waterway and the potential to stimulate algal growth and cause phytoplankton blooms; and a Secchi depth of $0.3 \mathrm{~m}$. The authors of that study as well as others $[20,21,22]$ suggest that nitrogen rather than phosphorous may be the limiting factor for algal or plant growth. It was recently identified in Chesapeake Bay that long-term reductions in nitrogen load led to expanded areas with nutrient limited phytoplankton [22]. The use of Equilibrium Resource Competition theory may be useful for managing the global increase of toxic algal blooms [23]. Water quality index is also a well-supported method of determining the health of a waterway [24].

At the time of the present study, many dugongs suffered mortality due to the loss of habitat and food source. An autopsy performed by a veterinarian from the Queensland Government Department of Primary Industries and Fisheries (Dr. Bruce Hill, pers. comm.) revealed invasion by a parasitic protozoan, Cryptosporidium. This parasite is rarely found in the marine environment, is usually restricted to terrestrial animals, birds and fresh to brackish water organisms [25]. Cryptosporidium is spread orally and has been associated with sewage outfalls. The increased carrying capacity of some whale watching vessels from 45 to 300 and the consequent increased discharge of untreated effluent in the bay was noted.

The aims of this study are to:

- establish a baseline water quality data set for the Hervey Bay region. This was the first time an extensive section of the coastline extending from the mouth of the Mary River in the northern part of The Great Sandy Strait to $20 \mathrm{~km}$ into the southern section of Hervey Bay had been monitored intensively (usually monthly and on occasion three times per month).

- identify changes in water quality with distance from a river and creeks with waste water treatment discharge

- determine monthly and seasonal changes in phytoplankton assemblage structure

- assess links between key water quality parameters and phytoplankton load and community structure

The data was collected between 1993 and 1995, and processed in 2009. Early reports to the Hervey Bay City Council in 1995 inspired a substantial upgrade to the sewerage treatment facilities to avoid future effluent discharge into Eli and Pulgul Creeks. Instead, the treated water could be used on market gardens and golf courses.

Trigger values and water quality targets remain identified as a current research need that has still not been addressed for Hervey Bay and similar regions. Therefore, water quality and its link to phytoplankton abundance and diversity continues to be a research priority in the critical area of coastal management in environmentally sensitive regions.

\section{METHOD}

A description of the survey area and sampling strategy are followed by the methods and statistical analyses used to assess water quality and phytoplankton diversity.

\subsection{SAMPLING AREA AND STRATEGY}

Between January and December 1993, a pilot water quality monitoring program surveyed 30 sites with sampling frequencies that ranged from once to 15 times during the year (figure 1). From examination of results plotted onto an aerial map and with consideration of distances from river and creek mouths and current and tidal knowledge, nine sites were selected for more vigorous assessment during 1994 (figure 2). Fortnightly surveys were conducted between January 1994 and February 1995 with some 
consideration of inclement weather, a total of 25 data sets were collected.

The decision to reduce the number of survey sites in 1994 was based on four factors. First, the major sources of nutrients entering Hervey Bay (i.e. the Mary River, Eli Creek and Pulgul Creek); second, knowledge that the Hervey Bay City Council was aware of the situation at Eli Creek [19] and had made a commitment to act on available data; third, knowledge of access to water quality data collected by the Department of Primary Industries Water Resources at local creeks and rivers and fourth, the need to select sites with low fluctuations in salinity.

Investigation of potential links between nutrient concentration and phytoplankton assemblage structure was the priority, so there was a need to reduce other known causes of variation as much as possible. In addition, it was considered important to acknowledge and characterise the identified critical habitats for Hervey Bay that support regional conservation by selecting survey sites within these habitats; intertidal, shallow and deep water seagrass sites were selected as they provide the main dietary source for dugongs and turtles; the Artificial Reef was selected as a diving destination and coral habitat and the areas offshore and at Coongal Point were selected as areas frequented by humpback whales. Coongal Point would also act as a depth control for Pulgul Creek and reflect seasonal changes of freshwater input into Hervey Bay from Coongal Creek on Fraser Island.

\subsection{PHYSICO-CHEMICAL PARAMETERS}

Depth profiles of temperature, $\mathrm{pH}$, dissolved oxygen and salinity at 1-meter intervals over the full depth of the water column were obtained using a Scout ${ }^{\circledR}$ Hydrolab Transmitter and logged to a laptop computer for later analysis. Sensors were calibrated before and after each field survey. Conductivity and $\mathrm{pH}$ were calibrated with standard solutions, while the oxygen sensor was calibrated using the atmospheric pressure method. Optical depth, or Secchi depth, was measured by a standard Secchi disc and recorded to the nearest $0.1 \mathrm{~m}$. Surface current speed and direction were measured with a survey boat at anchor by timing a buoyant object transit over a $10 \mathrm{~m}$ length. Wind speed and direction, sea state, visibility and percentage cloud cover were recorded at each site.

Water samples for Chl $a$ analyses were collected from a depth of $0.5 \mathrm{~m}$ below the surface and filtered on board through Whatman GF/C filters (median retention $0.7 \mu \mathrm{m}$ ). Each sample consisted of three subsamples collected within five minutes and combined to form one sample. Filters were drawn dry, folded, excess water removed by blotting with clean tissue, frozen immediately on dry ice and stored in darkness for analysis following the methods of Strickland and Parsons [34]. Filtration varied from 0.5L at Pulgul Creek (site 10) to 5L at the Outer Banks (site 18). Size fractionation of Chl $a$ was determined by repeating the filtration procedure on separate samples using Whatman No. 4 filters (median retention $20 \mu \mathrm{m}$ ).
Samples for nutrient analysis were collected at $0.5 \mathrm{~m}$ depth in $120 \mathrm{~mL}$ polypropylene containers pre-washed with phosphate free detergent, rinsed 5 times in reverse osmosis (RO) water, 3 times in MilliQ water and triple rinsed in seawater. Samples were either filtered through Sartorious $(0.45 \mu \mathrm{m})$ filters, pre-washed GF/C filtered or unfiltered, to compare collection methods. Duplicate and depth samples were taken at some sites to assess sampling and depth variation. Blanks were included in each analysis to confirm sampling and analytical techniques. Samples were frozen immediately on dry ice for analysis of SRP, $\mathrm{NO}_{\mathrm{x}}$ and ammonia $\left(\mathrm{NH}_{4}^{+}\right)$at the Government Chemical Laboratories.

Water clarity was assessed by measuring total suspended solids (TSS), turbidity and standard Secchi depth. A 4L sample consisting of $4 \times 500 \mathrm{~mL}$ sub-samples from a depth of $500 \mathrm{~mm}$ was stored in darkness for subsequent laboratory analysis. The sub-samples were combined into one sample and mixed before filtration through a pre-dried and weighed Whatman GF/C filter. Filters were dried to constant weight at $106^{\circ} \mathrm{C}$ and reweighed after cooling in a desiccator and TSS recorded as $\mathrm{mg} / \mathrm{L}$. Turbidity readings were measured using a Hach turbidimeter (model 2100A) in nephelometric turbidity units (NTU). The Secchi depth was recorded when the disc disappears from view at the surface of the water to indicate the point at which reflectance equals the intensity of light backscattered from the water. Position fixing of survey sites was achieved using a hand-held compass with reference to buoys and land marks.

\subsection{IDENTIFICATION AND ENUMERATIUON OF PHYTOPLANKTON}

Unfiltered $250 \mathrm{~mL}$ water samples collected from a depth of $0.5 \mathrm{~m}$ were preserved with acidified Lugol's solution and stored at $4^{\circ} \mathrm{C}$ for later microscopic analysis. Each sample consisted of three subsamples collected within five minutes and combined to form one sample. Concentration of samples was required and accomplished by centrifuging samples at low speed of $3,500 \mathrm{rpm}$ for 10 minutes $[27,32,33]$. The low-speed process ensured that delicate species remained intact with the advantages of reduced processing time, reduced storage volume $(250 \mathrm{~mL}$ concentrated to $2 \mathrm{~mL}$ ) and more efficient cell count. Samples were enumerated using a light microscope to view $0.05 \mathrm{~mL}$ of supernatant on an English Finder (ruling with 900 numbered squares) under a large glass cover slip. Identifications to genus level, and in some cases to species level, were possible at between $100 \times$ and $400 \times$ magnification. Identification was performed according to the identification keys in 'Identifying Marine Phytoplankton' [35] as well as other publications on specific genus [36,32,37]. At least 100 cells of each sample were counted, which gave $95 \%$ confidence intervals within $\pm 20 \%$ of the mean [38]. Counts were then extrapolated to provide concentrations per $\mathrm{mL}$ (cells $/ \mathrm{mL}$ ). A photographic identification catalogue of phytoplankton species in Hervey Bay was compiled. 


\subsection{STATISTICAL ANALYSES}

Monthly mean and standard deviations values, seasonal summaries, and maximum and minimum values were calculated for all physico-chemical data from the 1993, 1994 and 1995 surveys. Following appropriate data transformations [30], draftsmen plots were constructed using PRIMER (Plymouth Routines In Multivariate Ecological Research) by Clarke and Gorley [31] to reveal prominent correlations between key water quality parameters. Version (v5.0) was used for the following statistical analyses and although v7.0 is currently available, v5.0 is powerful, valid and effective.

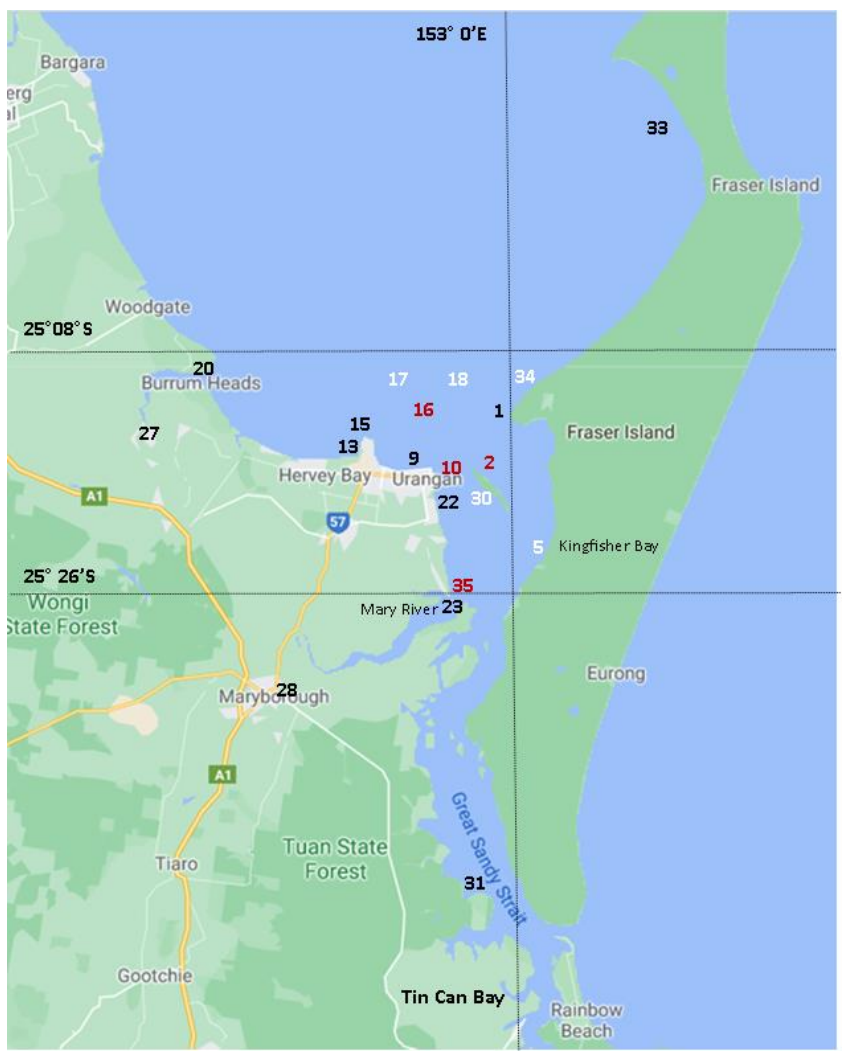

Figure 1: Sites surveyed in 1993 in Hervey Bay and the Great Sandy Straits (site details for depth, distance to nutrient source, annual mean, standard deviation and $N$ values for water quality parameters are presented in Appendix A). 1994 surveys - red and white numbers

Principle component analyses (PCA) were performed to construct a two-dimensional profile of survey sites that best represent their geographical separation on the basis of water/environmental/habitat quality and health status. Bubble plots were constructed to visualise the location of survey sites with relation to key univariate environmental measures. The results of this ordination technique were used to select four sites upon which the phytoplankton species assemblage analyses were performed. Rainfall data was summarised and plotted as monthly mean values for each catchment area and for the catchment as a whole.

Monthly phytoplankton data for 1994 and 1995 were logged and the cell density (cells/mL) calculated for each month for each of the nine sites. Univariate diversity indices of species richness (S), Margalef's Index (d), Pielou's evenness index (J'), Shannon diversity (H') and Simpson's index $(1-\lambda)$ were calculated, summarised and assessed in relation to rainfall, physico-chemical water parameters, algal blooms and anomalies. $\mathrm{S}$ and $\mathrm{H}$ ' were selected to best represent the changes identified in the data to produce the most meaningful and comprehensive interpretation of the results.

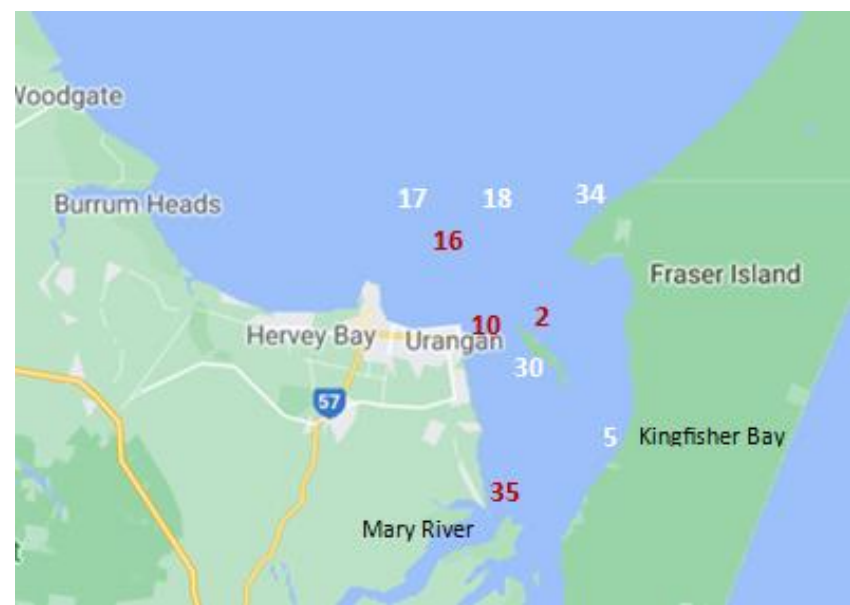

Figure 2: Survey sites for 1994 in Hervey Bay and the Great Sandy Straits (site details for depth, distance to nutrient source, annual mean, standard deviation and $\mathrm{N}$ values for water quality parameters, are presented in appendix B). Two nearshore and two offshore sites (red numbers).

The PRIMER software package was used to test hypotheses about multivariate differences among assemblages of phytoplankton at four sites: two near shore and two offshore. Hierarchical agglomerative clustering and non-metric multidimensional scaling (nMDS) were performed on a monthly and seasonal basis to determine the dominant links between the physico-chemical characteristics of water quality and biodiversity in the phytoplankton assemblages.

The BIOENV program in PRIMER matches biotic to environmental variables by rank correlation of (dis)similarity matrices. The ANOSIM2 test for a two-way crossed analysis with no replication was used to establish patterns of phytoplankton species composition between sites and between times (monthly and seasonal analyses). In order to identify which species primarily account for the observed assemblage differences between sites, the overall percentage contribution each species makes to the average dissimilarity between two groups was assessed using the SIMPER routine in PRIMER. This analysis determines species which are typical of a group, in that they are found in consistent abundance in most samples. The same species can often act as good discriminators between groups and therefore become indicator species for a particular habitat type or indicative for the status of environmental health at a particular site.

Differences in water quality parameters between near and offshore zones were tested by three-factor analysis of variance (ANOVA) using GMAV5 [28]. Treatment (four 
levels; season) was orthogonal and fixed, zones (two levels; near shore and offshore) were orthogonal and fixed and sites (two levels) were orthogonal and random with four replicates for each site. Data were examined for heterogeneity of variances using Cochran's test and means were compared by Student-Newman-Keuls (SNK) tests with transformations $\log (x+1)$ required $[39,40]$.

Phytoplankton species shown to be indicators and discriminators of sites within near and offshore zones using multivariate analyses SIMPER in PRIMER, were tested for significance by using the three-factor ANOVA seasonally for two sites, within two zones, each with three replicates.

\section{RESULTS}

The results of the water quality analyses and rainfall will be presented first followed by the phytoplankton assessment. A comparison between the water quality parameters of a dry February in 1994 and post flood February in 1995 is provided together with the species abundance and biodiversity comparison. Current 'trigger values' are then evaluated in light of the current research results.

\subsection{PHYSICAL AND CHEMICAL FACTORS}

The focus of this study was to identify water quality parameters linked to changes in phytoplankton assemblage structure. Nine sites were selected for monitoring in 1994 and were restricted to marine areas in order to reduce the effect of gross changes of salinity that may influence phytoplankton assemblage structure [41]. Annual mean and standard deviation values for all parameters are presented in Appendix A (1993) and Appendix B (1994). N values are presented in Appendix C. Annual mean and standard deviation values for some of the physico-chemical water quality parameters assessed in 1993 are presented graphically in Appendix D.

Average monthly values for local rainfall (A), Chl $a$ (B), SRP (C) and TSS (D) for the Artificial Reef (site 2), Pulgul Creek (site 10), the S2 Buoy (site 16) and the Mary River mouth (site 35) in 1994 are presented in figure 4. The number of sites presented is reduced to four (two near shore and two offshore) to coincide with sites assessed for phytoplankton species assemblage structure. In addition, standard deviation values are presented in Appendix $\mathrm{E}$ in preference to graphical presentation to reduce cluttering on graphs.

\subsection{RAINFALL AND LINKS TO WATER QUALITY}

Monthly rainfall for the catchment is plotted in figure 3(A) and incorporates readings for Pialba, Urangan, Maryborough, Burrum, Howard, Torbanlea and Gympie. The rainfall for local areas is presented in figure 3(B) and plots readings for Urangan and Maryborough in 1994. The comparison shows clearly the difference between catchment and local rainfall.

The trend in peaks for water quality parameters coincides generally with local rainfall. The values measured for all water quality parameters at near shore sites (site 10; Pulgul Creek and site 35; Mary River mouth) are higher than for offshore sites (site 2; Artificial Reef and site 16) to indicate a water quality gradient. An exception to this trend is in October at Pulgul Creek (site 10) when an increase in Chl $a$ (from $0.86 \pm 0.06$ to $2.0 \pm 0.15 \mu \mathrm{g} / \mathrm{L}$ ) coincides with a decrease in SRP concentration (from $8.54 \pm 8.32 \mu \mathrm{g} / \mathrm{L}$ to $3.0 \pm 0 \mu \mathrm{g} / \mathrm{L}$ ). Conversely, the Mary River mouth (site 35) experienced a slight increase in SRP in October and a decrease in Chl $a$. The offshore sites (site 2; Artificial Reef and site 16; S2 Buoy) experienced an increase in both SRP and Chl $a$ between September and October.

\subsection{WATER QUALITY GRADIENT AND SEASONAL TRENDS}

Results of the cluster analysis performed on seasonally averaged water quality data for each site are presented in figure 5. The dendrogram shows clearly a seasonal separation of survey sites on the basis of water quality and within this seasonal separation, similarity of near shore sites (site 2; Artificial Reef and site 16; S2 Buoy) in summer, autumn and spring. Sites 16 and 35 (Mary River) appear more similar in winter however, site 35 is more similar to site 10 (Pulgul Creek) on the basis of water quality in autumn and spring. Site 10 is far removed from all sites for the summer water quality assessment.
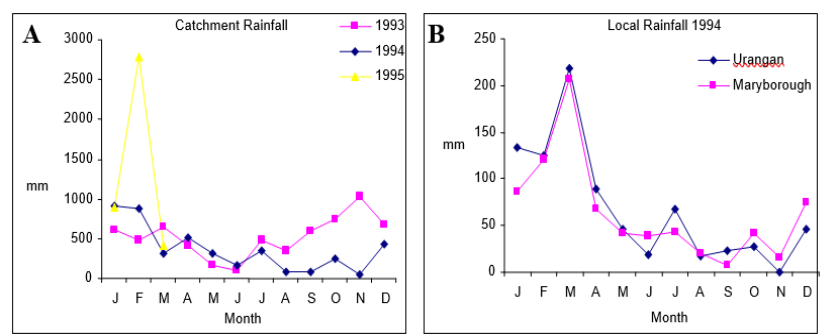

Figure 3: Monthly rainfall (mm) for $(\mathrm{A})$ the catchment area in 1993, 1994 and 1995 and (B) local region (Maryborough and Urangan) in 1994.

Low rainfall in June coincided with low TSS measurements at all sites followed by increased rainfall in July and associated increase in all TSS measurements. Rainfall is also well reflected in the SRP and to a lesser degree with $\mathrm{Chl} a$ concentration at near shore sites. Total suspended solids (TSS, figure 4D) increased in March and April at near shore sites following high rainfall in March however, only a slight increase in rainfall for September and October, produced increased measurements for all parameters at near and offshore sites. Larger increases in rainfall in July did not produce such an effect on the offshore sites previously. This observation unlinks rainfall from nutrient concentration and introduces another potential source of nutrients to offshore sites. The population of Hervey Bay increases dramatically between August and October each year in response to commercial whale watching, which in 1994, may have influenced nutrient loading to the bay.

Appendix E presents a seasonal summary of the physicochemical parameters monitored at four of the nine sites surveyed in 1994. The seasonal pattern of water quality 
trends between near and offshore sites led to the analyses of phytoplankton assemblage structure on a seasonal basis.

The bubble overlay of $\mathrm{Chl} a$ on the principal component analyses (PCA) of seasonal water quality in figure 6 shows that $\mathrm{Chl} a$ concentration is a strong influence on the arrangement of sites. This finding indicates a clear geographical basis to the water quality gradient that exists from near shore to offshore sites in Hervey Bay. The grouping of offshore sites (site 2; Artificial Reef and site 16; S2 Buoy) in all seasons is noted together with the clustering of near shore sites (site 10; Pulgul Creek and site 35; Mary River mouth) in autumn and winter. Pulgul Creek (site 10) becomes more distant from the Mary River mouth (site 35) in spring and is quite isolated in summer. This is probably due to the extremely elevated Chl $a$ (2.0 to 4.7 $\mu \mathrm{g} / \mathrm{L}$ ) and suspended sediment (20.6 to $22.4 \mathrm{mg} / \mathrm{L}$ ) concentrations from October to December. These peaks coincide with trends in spring and summer rainfall. The results of the PCA (figure 6) reflect closely those of the cluster analysis in figure 5 .
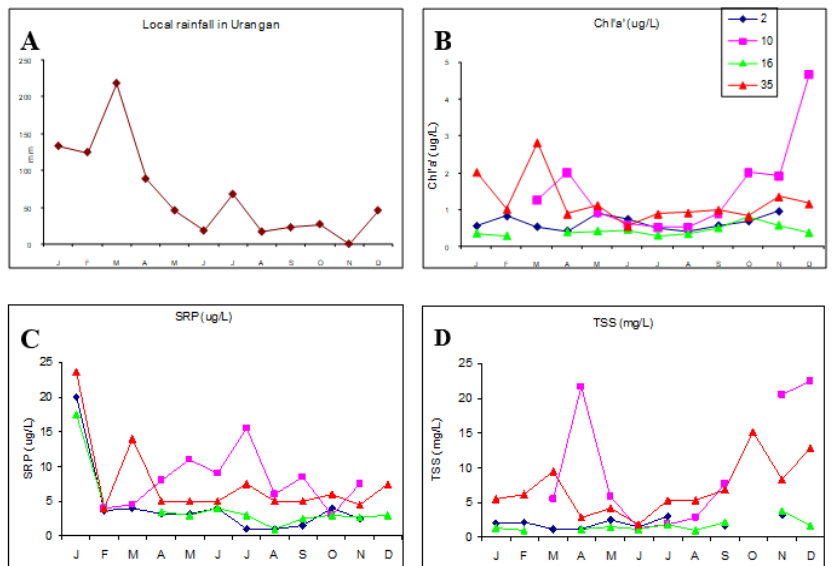

Figure 4. Monthly average A local rainfall $(\mathrm{mm})$ B Chl a $(\mu \mathrm{g} / \mathrm{L})$ C SRP $(\mu \mathrm{g} / \mathrm{L})$ and D TSS $(\mathrm{mg} / \mathrm{L})$ for near shore (site 35; Mary River mouth and site 10; Pulgul Creek) and offshore (site 2; Artificial Reef and site 16; S2 buoy) sites in 1994. To avoid cluttering, monthly, seasonal and annual mean and standard deviation values are presented in Appendices B, E and $F$.

The results of the three factor analyses of variance are presented in table 2. Seasonal and zone differences were significant for many of the water quality parameters monitored in Hervey Bay during 1994. Water clarity measures consistently showed significant differences between near and offshore zones (Secchi depth; $\mathrm{P}<0.01$, turbidity; $\mathrm{P}<0.05$ and TSS; $\mathrm{P}<0.01$ ). Seasonal differences were apparent at the near shore zone with a highly significant difference between near and offshore zones in summer, autumn and spring $(\mathrm{P}<0.01)$. There was no difference in water clarity measures between near and offshore zones in winter months. Water temperature was significantly lower $(\mathrm{P}<0.01)$ in winter than for autumn and spring which all recorded significantly lower temperatures than summer $(\mathrm{P}<0.05)$.
There was no difference between the oxygen concentration at near and offshore zones during summer and winter months with the lowest oxygen conditions in the water column in summer $(\mathrm{P}<0.05)$ and highest during the winter months. Near shore sites experienced significantly lower $(\mathrm{P}<0.01)$ oxygen conditions than offshore sites in spring while offshore sites had lower $(\mathrm{P}<0.05)$ oxygen conditions in autumn compared to near shore sites. The near shore zone, with survey sites located close to river (site 35, Mary River) and creek mouths (site 10, Pulgul Creek), produced higher SRP concentrations than for sites in the offshore zone $(\mathrm{P}<0.05) . \mathrm{NO}_{\mathrm{x}}$ concentrations were found to be greater during summer months than for other times of the year $(\mathrm{P}<0.01)$ and higher in near shore zones than offshore $(\mathrm{P}<0.01)$. Chl $a$ concentration was significantly greater $(\mathrm{P}<0.01)$ at the near shore zone than for the offshore zone while $\mathrm{pH}$ was consistently lower and therefore more acidic near shore than for the offshore zone. ANOVA results provides valuable support to the multivariate analyses.

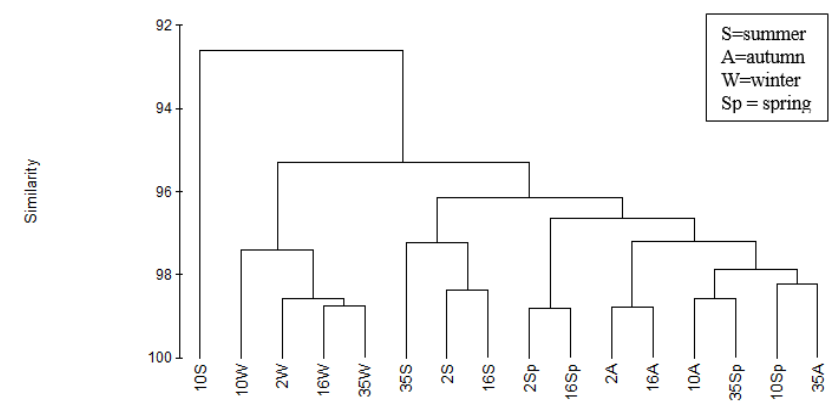

Figure 5: Cluster analysis for seasonal water quality parameters in Hervey Bay in 1994 (site 35; Mary River mouth, site 10; Pulgul Creek, site 2; Artificial Reef, site 16; S2 buoy).

\subsection{SEASONAL TRENDS IN PHYTOPLANKTON DIVERSITY AND ASSEMBLAGE STRUCTURE}

Figure 7 shows monthly phytoplankton cell density at each site. Cell densities at the Mary River mouth (site 35) are greater than other sites for most of the year however the Chl $a$ concentration (figure 4B) at Pulgul Creek (site 10) in April, October, November and December are greater than for the Mary River (site 35). Maximum cell density of 258 cells/mL occurred in March at the Mary River mouth (site 35) and corresponds to peaks in rainfall, Chl $a$, SRP and TSS (figure 4A, 4B, 4C and 4D, respectively) however, rainfall is not coincident with the peak cell density of 196 cells $/ \mathrm{mL}$ in May. There were also slight increases in Chl $a$ at the Mary River mouth (site 35) and SRP concentrations at Pulgul Creek (site 10) at this time (figure 4B and 4C).

A sharp increase in cell density occurred at the S2 Buoy (site 16) in September to peak at 100 cells $/ \mathrm{mL}$ in October however the Chl $a$ concentration did not mimic this trend. This may be due to diatoms containing more Chl $a$ than Trichodesmium cells. Pulgul Creek (site 10) and the Mary River mouth (site 35) saw a similar increase in cell density as the S2 Buoy (site 16) in September but these remained the same in October at Pulgul Creek (site 10) and dropped 
in October at the Mary River mouth (site 35). Pulgul Creek (site 10) reached a maximum of 135 cells $/ \mathrm{mL}$ in November when the minimum rainfall occurred but then as cell density decreased in December for this site, the $\mathrm{Chl} a$ increased to a maximum of $4.7 \mu \mathrm{g} / \mathrm{L}$ with a slight increase in rainfall. This may indicate the presence of a larger diatom species or species with more pigment per unit volume at this time. Chlorophyta sp. dominated the cell counts for this month.

Table 1: Seasonal water quality summary for near (site 10; Pulgul Creek, site 35; Mary River mouth) and offshore sites (site 2; Artificial Reef, site 16; S2 buoy) in 1994. Average (top) and standard deviation (below) values are presented.

\begin{tabular}{|c|c|c|c|c|c|c|c|c|c|c|c|c|}
\hline Season & Site & $\begin{array}{l}\text { Colla } \\
\mathrm{pg} / \mathrm{L}\end{array}$ & $\begin{array}{c}\text { Secchi } \\
\mathrm{m}\end{array}$ & $\begin{array}{l}\text { SRP } \\
\mu \mathrm{g} / \mathrm{L}\end{array}$ & $\begin{array}{l}\mathrm{NOx} \\
\mu \mathrm{g} / \mathrm{L}\end{array}$ & $\begin{array}{c}\mathrm{NH}_{4}+{ }^{+}+ \\
\mathrm{gLL}\end{array}$ & $\begin{array}{l}\text { Temp } \\
{ }^{\circ} \mathrm{C}\end{array}$ & $\mathrm{pH}$ & $\begin{array}{c}\text { Salinity } \\
\text { ppt }\end{array}$ & Oxygen & $\begin{array}{l}\text { TSS } \\
\mathrm{Mg} / \mathrm{L}\end{array}$ & $\begin{array}{c}\text { Turbidity } \\
\text { NTU }\end{array}$ \\
\hline \multirow[t]{2}{*}{ Summer } & 2 & 0.67 & 5.88 & 4.00 & 4.38 & 29.13 & 27.55 & 8.17 & 37.30 & 6.94 & 2.04 & 1.10 \\
\hline & & 0.19 & 0.18 & 0.00 & 1.24 & 12.90 & 0.81 & 0.06 & 0.00 & 0.19 & 0.07 & 0.61 \\
\hline \multirow[t]{2}{*}{ Autumn } & & 0.60 & 4.80 & 3.46 & 2.54 & 17.54 & 24.35 & 8.08 & 36.05 & 7.02 & 1.64 & 1.07 \\
\hline & & 0.25 & 1.44 & 0.47 & 1.71 & 5.05 & 4.23 & 0.06 & 0.92 & 0.14 & 0.73 & 0.39 \\
\hline \multirow[t]{2}{*}{ Winter } & & 0.54 & 5.47 & 2.00 & 1.00 & 6.50 & 18.50 & 7.90 & 36.70 & 8.11 & 2.21 & 1.45 \\
\hline & & 0.17 & 0.31 & 1.73 & 0.00 & 0.50 & 0.00 & 0.00 & 0.00 & 0.00 & 1.11 & 0.10 \\
\hline \multirow[t]{2}{*}{ Spring } & & 0.72 & 3.83 & 2.67 & 1.00 & 5.75 & 23.33 & 7.99 & 37.30 & 7.55 & 2.44 & 1.83 \\
\hline & & 0.19 & 0.74 & 1.26 & 0.00 & 0.66 & 2.92 & 0.03 & 1.41 & 0.27 & 1.09 & 1.32 \\
\hline \multirow[t]{2}{*}{ Summer } & 10 & 2.62 & 1.40 & 5.50 & 3.00 & 19.50 & 26.04 & 8.01 & 38.70 & 6.07 & 12.01 & 4.58 \\
\hline & & 2.89 & & 2.12 & 2.83 & 6.36 & 0.00 & 0.00 & 0.00 & 0.00 & 14.73 & 5.06 \\
\hline \multirow[t]{2}{*}{ Autumn } & & 1.38 & 0.80 & 7.83 & 7.33 & 22.61 & 23.48 & 7.99 & 34.85 & 7.39 & 11.01 & 5.37 \\
\hline & & 0.56 & & 3.25 & 5.03 & 9.06 & 4.34 & 0.12 & 2.47 & 1.09 & 9.22 & 4.01 \\
\hline \multirow[t]{2}{*}{ Winter } & & 0.53 & 1.40 & 10.17 & 2.83 & 9.42 & 17.53 & 7.92 & 36.38 & 7.94 & 1.97 & 1.63 \\
\hline & & 0.05 & 0.17 & 4.86 & 0.76 & 3.11 & 0.58 & 0.07 & 0.04 & 0.89 & 0.71 & 0.31 \\
\hline \multirow[t]{2}{*}{ Spring } & & 1.59 & 1.23 & 6.35 & 3.75 & 11.35 & 23.53 & 7.95 & 37.97 & 6.91 & 14.12 & 7.07 \\
\hline & & 0.63 & & 2.94 & 2.46 & 5.53 & 2.68 & 0.05 & 1.16 & 0.55 & 9.13 & 5.16 \\
\hline \multirow[t]{2}{*}{ Summer } & 16 & 0.31 & 6.68 & 4.25 & 5.40 & 52.13 & 27.44 & 8.12 & 37.00 & 6.75 & 1.20 & 0.98 \\
\hline & & 0.05 & & & 0.00 & 20.33 & 0.84 & 0.06 & 0.21 & 0.57 & 0.26 & 0.55 \\
\hline \multirow[t]{2}{*}{ Autumn } & & 0.39 & 5.81 & 3.25 & 1.75 & 13.83 & 22.95 & 7.99 & 36.35 & 7.10 & 1.28 & 0.91 \\
\hline & & 0.02 & & & & 8.72 & 2.48 & 0.08 & 0.92 & 0.14 & 0.20 & 0.04 \\
\hline \multirow[t]{2}{*}{ Winter } & & 0.35 & 4.80 & 2.67 & 1.00 & 6.17 & 17.55 & 7.93 & 36.80 & 8.11 & 1.38 & 1.19 \\
\hline & & 0.08 & & & & 0.52 & 0.02 & 0.07 & 0.00 & 0.23 & 0.44 & 0.13 \\
\hline \multirow[t]{2}{*}{ Spring } & & 0.61 & 4.5 & 2.75 & 1.00 & 8.17 & 23.05 & 7.96 & 37.55 & 7.39 & 3.07 & 1.97 \\
\hline & & 0.17 & & 0.25 & 0.00 & 2.47 & 2.09 & 0.10 & 0.87 & 0.15 & 1.17 & 0.90 \\
\hline \multirow[t]{2}{*}{ Summer } & 35 & 1.50 & 2.25 & 13.88 & 2.38 & 15.88 & 27.55 & 8.12 & 36.83 & 6.60 & 5.90 & 2.33 \\
\hline & & 0.71 & & 13.97 & & 2.65 & 1.12 & 0.06 & 0.04 & 0.18 & 0.50 & 0.74 \\
\hline \multirow[t]{2}{*}{ Autumn } & & 1.59 & & 8.00 & 15.97 & 13.89 & 24.52 & 8.01 & 32.20 & 7.12 & 5.49 & 3.00 \\
\hline & & 1.06 & & & 25. & 4.10 & 2.91 & 0.05 & 6.27 & 0.67 & 3.51 & 1.20 \\
\hline \multirow[t]{2}{*}{ Winter } & & 0.77 & 3.10 & 5.83 & 1.3 & 6.67 & 17.81 & 7.93 & 35.60 & 8.19 & 4.13 & 2.09 \\
\hline & & 0.20 & & 1.44 & 0.58 & 0.76 & 0.05 & 0.04 & 0.00 & 0.41 & 2.03 & 0.56 \\
\hline \multirow[t]{2}{*}{ Spring } & & 1.04 & 1.70 & 5.17 & 2.17 & 8.17 & 24.28 & 7.93 & 36.97 & 7.09 & 10.10 & 4.90 \\
\hline & & 0.27 & 0.00 & 0.76 & 1.61 & 3.40 & 2.29 & 0.10 & 1.40 & 0.53 & 4.45 & 1.00 \\
\hline
\end{tabular}

Initial assessment for phytoplankton counts and species diversity was conducted for nine sites during 1994 however detailed analyses of assemblage structure and links to water quality was assessed at four sites - two near shore sites at the Mary River (site 35) and Pulgul Creek (site 10) and two sites following the water quality gradient offshore into the bay: The Artificial Reef (site 2) and the S2 Buoy (site 16). Considering all nine sites, figure $8 \mathrm{~A}$ shows that the species richness for the near and offshore sites, where greater seasonal changes were observed than for the species richness of intermediate sites presented in figure 8B.

Agglomerative hierarchical cluster analysis performed on the seasonal phytoplankton assemblages is represented in the dendrogram illustrated in figure 9. This shows a seasonal component to the phytoplankton assemblage structure for each site with seasonal groupings of near and offshore sites. Some similarities are noted with the geographical location of sites to the cluster dendrogram for water quality parameters (figure 5) where the summer assemblage for Pulgul Creek (site 10) is well removed from the other sites. Also, the winter assemblages for the Mary River mouth (site 35), the Artificial Reef (site 2) and the S2 Buoy (site 16) are grouped in the same pattern as they are for water quality (figure 5).

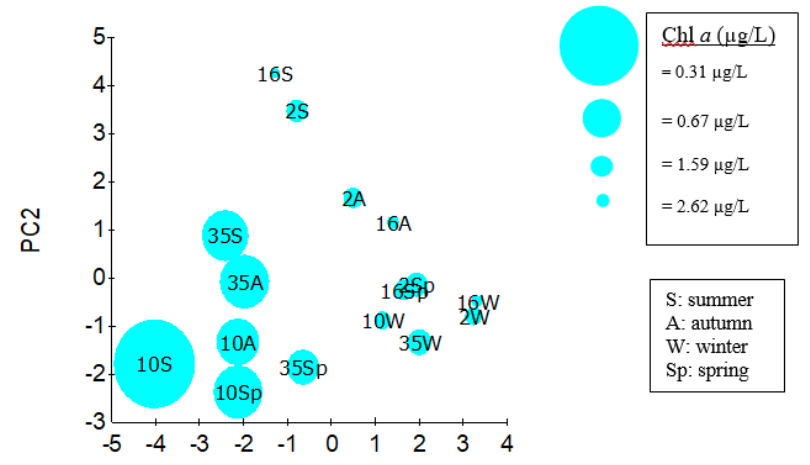

PC1

Figure 6: Principal component analysis (PCA) plot for 1994 seasonal water quality parameters presented in table 3-2 with bubble overlay of $\mathrm{Chl}$ a $(\mu \mathrm{g} / \mathrm{L}$ ) values (site 35; Mary River mouth, site 10; Pulgul Creek, site 2; Artificial Reef; site 16; S2 Buoy).

Margalef's species richness and Pielou's evenness values calculated for each site with increasing distance from nutrient sources (Appendix G) support species richness data (figure 8). Phytoplankton assemblages displayed similar seasonal trends at each site for evenness but the S2 Buoy (site 16) showed more extreme seasonal changes in species richness than the near shore sites. This offshore site showed maximum diversity and evenness in summer and winter with minimum diversity and evenness in autumn and spring. The sites closer to shore experienced minimum diversity in summer with a maximum and relatively consistent diversity in autumn, winter and spring. A summary of mean and standard deviation values for seasonal phytoplankton species diversity is presented in Appendix H.

Non-parametric multi-dimensional scaling (nMDS) of seasonal phytoplankton assemblages at the two nearshore and two offshore sites shows that site differences are apparent (figure 10, stress 0.17) within the seasonal assessment. The nMDS shows that summer and winter assemblages for Pulgul Creek (site 10) are distant and therefore quite distinct in structure from the Artificial Reef (site 2), the S2 buoy (site 16) and the Mary River mouth (site 35). Winter assemblages for the Artificial Reef (site 2), the S2 buoy (site 16) and the Mary River mouth (site 35) are clustered to indicate similarity but in summer, the assemblages for these sites are more distinct. In autumn, the sites are evenly spaced with the assemblages for the Artificial Reef (site 2) and the S2 buoy (site 16) being further from those at Pulgul Creek (site 10) and the Mary River mouth (site 35). In spring, the assemblages at offshore sites were more similar than the near shore site assemblages. The nMDS pattern for phytoplankton assemblage structure (figure 10) is similar to the PCA pattern for water quality (figure 6). This similarity shows that the geographical separation of sites with distance from nutrient and sediment sources of rivers, creeks, sewerage effluent discharge points and general land runoff including storm water, is reflected in the changes to water quality and hence, phytoplankton community structure. The results of 
the multivariate dispersion analysis MVDISP support the nMDS findings.

Table 2: Summary of three factor analyses of variance for selected water quality parameters in Hervey Bay in $1994(n=4)$. F-ratios in bold calculated after post-hoc pooling at $P>0.25$ (Winer et al., 1991). Data were examined for heterogeneity of variance using Cochran's C-tes and were transformed to $\log (x+1)$ before analysis (Underwood 1981 1997); *significant at $P<0.05$, ${ }^{\star \star} P<0.01$.

\begin{tabular}{|c|c|c|c|c|c|c|c|}
\hline \multirow[b]{2}{*}{ Source of variation } & \multirow[b]{2}{*}{ df } & \multicolumn{2}{|c|}{$\begin{array}{l}\text { Secchi Depth } \\
\mathrm{C}=0.22\end{array}$} & \multicolumn{2}{|c|}{$\begin{array}{l}\text { Turbidity } \\
C=0.76\end{array}$} & \multicolumn{2}{|c|}{$\begin{array}{c}\text { TSS } \\
\mathrm{C}=0.13\end{array}$} \\
\hline & & & $\mathrm{F}$ & MS & $\mathrm{F}$ & MS & F \\
\hline Season & 3 & 2.41 & 2.81 & 0.89 & 1.72 & 1.22 & 2.93 \\
\hline Zone & 1 & 219.48 & 12.96 & 9.30 & 10.79 & 3.80 & 25.45 \\
\hline Site & 1 & 0.88 & 0.59 & 0.29 & 1.62 & 0.002 & 0.01 \\
\hline Sex Zo & 3 & 2.78 & 8.30 & 0.77 & $4.30^{*}$ & 1.23 & $7.17^{* \star}$ \\
\hline $\mathrm{Sex} \mathrm{Si}$ & 3 & 0.86 & 0.57 & 0.52 & $2.91^{*}$ & 0.42 & 2.43 \\
\hline $\mathrm{ZoxSi}$ & 1 & 16.93 & $11.31^{* *}$ & 0.86 & $4.85^{\star}$ & 0.54 & 3.17 \\
\hline Se $x \mathrm{Zo} \times \mathrm{Si}$ & 3 & 0.34 & 0.22 & 0.08 & & & \\
\hline Residual & 48 & 1.5 & & 0.18 & & & \\
\hline
\end{tabular}

\begin{tabular}{|c|c|c|c|c|c|c|c|}
\hline & & & & & & & \\
\hline Source of variatio & $d f$ & MS & $\mathrm{F}$ & MS & $\mathrm{F}$ & MS & $\mathrm{F}$ \\
\hline Season & 3 & 0.34 & 1.82 & 1.81 & $16.29 *$ & 0.13 & 3.26 \\
\hline Zone & 1 & 7.71 & $648.89^{*}$ & 2.43 & $9.14^{* *}$ & 1.80 & $27.76^{* \star}$ \\
\hline Site & 1 & 0.15 & 1.00 & 0.94 & 3.52 & 0.15 & 2.31 \\
\hline Se $x Z_{0}$ & 3 & 0.33 & 2.21 & 0.33 & 1.25 & 0.10 & 1.56 \\
\hline $\mathrm{SexSi}$ & 3 & 0.19 & 1.29 & 0.11 & 0.42 & 0.04 & 0.60 \\
\hline $\mathrm{ZoxSi}$ & 1 & 0.01 & 0.08 & 1.29 & & 0.08 & \\
\hline Sex ZoxSi & 3 & 0.08 & & 039 & & 001 & \\
\hline Residual & 48 & 0.15 & & 024 & & 0.07 & \\
\hline
\end{tabular}

\begin{tabular}{|c|c|c|c|c|c|c|c|}
\hline & \multicolumn{3}{|c|}{$\begin{array}{c}\mathrm{pH} \\
\mathrm{CH}=0.28\end{array}$} & \multicolumn{2}{|c|}{$\begin{array}{c}\text { Temperature } \\
\mathbf{C}=\mathbf{0 . 1 4}\end{array}$} & \multicolumn{2}{|c|}{$\begin{array}{l}\text { Oxygen } \\
\mathrm{C}=0.19\end{array}$} \\
\hline Source of variation & df & MS & F & MS & F & & \\
\hline Season & 3 & 0.0008 & 5.3 & 0.36 & $46.34^{*}$ & 0.05 & $25.58^{*}$ \\
\hline Zone & 1 & 0.0007 & $7.00^{* *}$ & 0.002 & $170.96^{*}$ & 0.003 & 0.05 \\
\hline Site & 1 & 0.0003 & 3.00 & 0.02 & 1.98 & 0.006 & 0.28 \\
\hline Se x Zo & 3 & 0.0001 & 1.00 & 0.003 & 0.67 & 0.002 & $20.45^{*}$ \\
\hline $\mathrm{Sex} \mathrm{Si}$ & 3 & 0.0000 & 1.00 & 0.01 & 1.03 & 0.005 & 0.45 \\
\hline $\mathrm{ZoxSi}$ & 1 & 0.0000 & & 0.00 & 0.00 & 0.0003 & 1.14 \\
\hline Sex ZoxSi & 3 & 0.0000 & & 0.01 & 0.64 & 0.01 & 0.07 \\
\hline Residual & 48 & 0.0001 & & 0.07 & & & \\
\hline
\end{tabular}

The ANOSIM2 test for an unreplicated 2-way layout (analysis of similarities without replication) operates on the phytoplankton species similarity matrix (rank) to test for differences between locations (sites) and times (seasons). An average of all the pair-wise correlations of $\rho a v=0.81$ was calculated between the among-site similarity matrices for each season. A significance level at $\mathrm{P}<0.001$ was determined by a Monte Carlo test with 999 simulations to conclude significant site differences on the basis of seasonal phytoplankton assemblages.

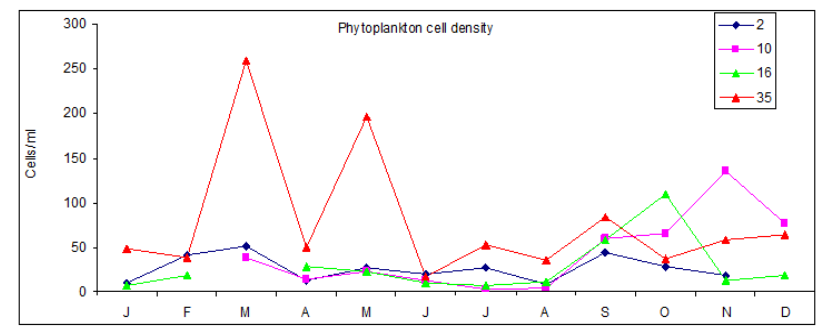

Figure 7: Monthly phytoplankton cell density (cells $/ \mathrm{mL}$ ) for two near shore 1994 (site 35; Mary River mouth, site 10; Pulgul Creek) and two offshore zones (site 2; Artificial Reef; site 16; S2 Buoy) in Hervey Bay. Single counts per month; measure of variation not available.

Diatoms dominated the phytoplankton composition for all sites and seasons, making up to between 58\% and 97\% of the species structure as shown in table 3 . The minimum of $58 \%$ of diatoms occurred at the S2 buoy during spring (October) when a bloom of the cyanobacteria Trichodesmium $s p$. accounted for $37 \%$ of the phytoplankton cell count. Dinoflagellates were least abundant at Pulgul Creek (site 10) and the Mary River mouth (site 35) at $0.2 \%$ to $1.0 \%$ respectively but made up to between $3.2 \%$ and $10 \%$ of the phytoplankton assemblage at The Artificial Reef (site 2) and the S2 Buoy (site 16). Coccoliths peaked at $5.6 \%$ in winter and phytoflagellates at $14.8 \%$ in summer at site 10 .

Annual mean values for each of the 150 phytoplankton species identified in Hervey Bay were calculated for each site to determine presence and absence information. The species listed in table 4, in columns listed from left to right represent; 'presence only': species found only at these sites; 'absence only': species not identified at this site but present at all other sites in 1994; 'gradient from site 35 and site 10': these species are found in higher abundances at sites 35 and 10 specifically, (i.e. river as a nutrient source or source containing treated sewage effluent) than at sites further offshore; 'opposite gradient': these phytoplankton species were found in lower abundance near nutrient sources and in higher abundance at offshore sites; 'nutrient source': this species found at both river and creek nutrient sources: site 10 (Pulgul Creek) and site 35 (Mary River mouth).
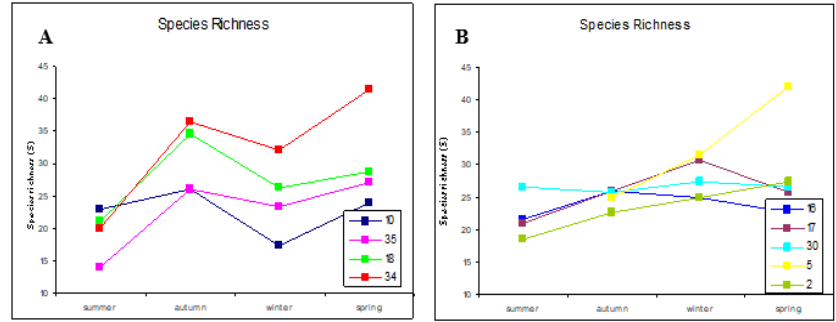

Figure 8: Seasonal phytoplankton species richness (S) for nine survey sites at (A) near shore and offshore sites and for (B) sites in the intermediate zone between near and offshore sites in Hervey Bay in 1994 (see Appendix E for standard deviation values).

Table 5 lists the three dominant species and their respective percentages, that contribute to the seasonal similarity at each site. Cylindrotheca closterium dominated the phytoplankton assemblage structure at nutrient source, near shore sites at Pulgul Creek (site10) and the Mary River Mouth (site 35) for most of the year. The exception to this was at the Mary River Mouth (site 35) in summer when Thalassionema nitzschioiodes dominated at $54 \%$ and for Pulgul Creek (site 10) in autumn, when Chaetoceros sp. dominated at 37\%. Rhizosolenia sp. dominated the assemblages at the Artificial Reef (site 2), except in summer when Leptocylindrus danicus bloomed at 55\%. Rhizosolenia sp. was also in the top 3 'typical' species for each season except in summer at the S2 Buoy (site 16). The dominance changed for each season at the S2 Buoy (site 16) with Chromophyta species and Cylindrotheca closterium in summer, Rhizolsolenia sp. in autumn, Thalassiosira $s p$. in winter and the potentially hazardous cyanobacteria Trichodesmium sp. in spring. 


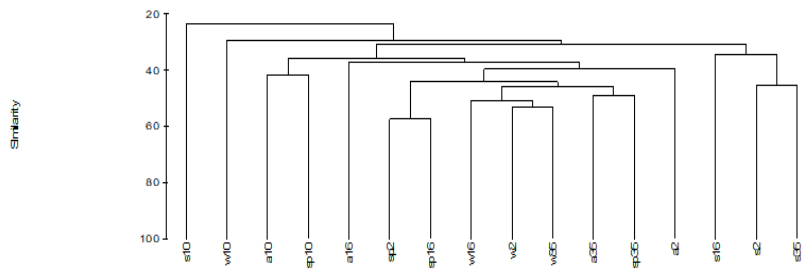

Figure 9: Dendrogram of cluster analysis for seasonal phytoplankton assemblages at two near shore sites (site 35; Mary River mouth, site 10 Pulgul Creek) and two offshore sites within the offshore zone (site 2; Artificial Reef, site 16; the S2 Buoy) in Hervey Bay in 1994.

The phytoplankton species that primarily account for the observed assemblage differences between sites and similarities within sites were investigated using SIMPER (similarity of percentages) in PRIMER. This program looks at the overall percentage contribution that each species makes to the average dissimilarity between two groups. The results of the SIMPER analysis provide quantitative information (\%) and species lists to support the seasonal separation of sites observed in the nMDS ordination plot (figure 10). That is, site separation and hence water quality differentiation on the basis of phytoplankton biodiversity.

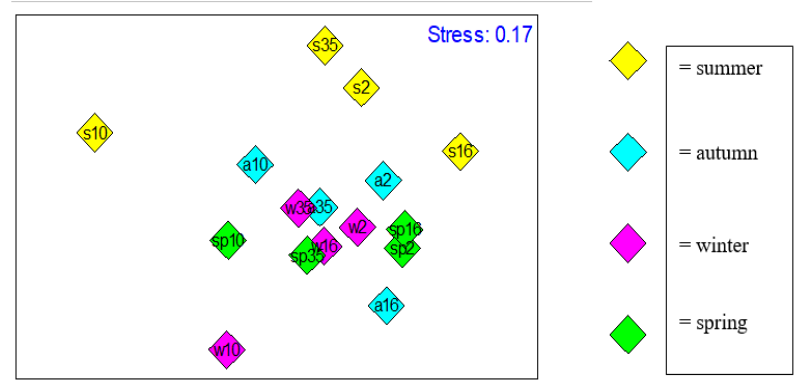

Figure 10: Non-parametric multidimensional scaling (nMDS) of seasona phytoplankton assemblages for The Artificial Reef (site 2), Pulgul Creek (site 10), the S2 Buoy (site 16) and the Mary River mouth (site 35); stress 0.17 , in 1994 .

Table 6 summarises the results of the SIMPER analysis and expresses the dissimiliarity between phytoplankton assemblages for each site and season as a percentage. The sites most dissimilar are 10 and 16 in spring and sites least dissimilar (i.e. most similar) are the Artificial Reef (site 2) and the Mary River mouth (site 35) in winter. The sites most similar and dissimilar changed with season. Annually, the average dissimilarity in phytoplankton assemblage structure is greatest between sites 10 and 16 at $88 \%$, and least dissimilar (most similar) between sites 2 and 35 at 77.5\%. The average similarity between the Artificial Reef (site 2) and the S2 Buoy (site 16) was close at $78 \%$.

Table 3: Percentages of phytoplankton groups for each site (site 2; Artificial Reef, site 10; Pulgul Creek, Site 16; the S2 Buoy, Site 35; Mary River mouth) and season ( $\mathrm{s}=$ summer, $\mathrm{a}=$ autumn, $\mathrm{w}=$ winter and $\mathrm{sp}=$ spring).

\begin{tabular}{|l||rrrr||rrrr|rrrr||rrrr|}
\hline$\%$ & \multicolumn{1}{|c|}{ s2 } & \multicolumn{1}{c|}{ 22 } & w2 & \multicolumn{1}{c|}{ sp2 } & s10 & a10 & w10 & \multicolumn{1}{c|}{ sp10 } & s16 & a16 & w16 & sp16 & s35 & a35 & W35 & sp35 \\
\hline \hline Diatoms & 91.6 & 96.1 & 94.0 & 86.2 & 84.3 & 96.1 & 91.0 & 96.6 & 87.2 & 92.1 & 93.5 & 57.7 & 95.1 & 97.1 & 92.4 & 97.3 \\
Dinoflagellates & 3.2 & 3.4 & 5.5 & 10.2 & 0.9 & 2.8 & 3.4 & 0.2 & 4.7 & 4.9 & 5.9 & 5.2 & 1.1 & 1.2 & 6.0 & 1.4 \\
Coccoliths & 0.6 & 0.2 & 0.0 & 0.0 & 0.0 & 0.0 & 5.6 & 0.0 & 1.2 & 2.2 & 0.7 & 0.0 & 0.5 & 1.0 & 0.0 & 0.0 \\
Cyanobacteria & 0.0 & 0.3 & 0.0 & 2.2 & 0.0 & 0.0 & 0.0 & 0.2 & 1.2 & 0.0 & 0.0 & 36.6 & 0.5 & 0.0 & 1.2 & 0.0 \\
Phyyoflagellates & 2.6 & 0.0 & 0.0 & 1.2 & 14.8 & 0.4 & 0.0 & 2.3 & 4.7 & 0.0 & 0.0 & 0.1 & 2.7 & 0.3 & 0.2 & 1.1 \\
\hline
\end{tabular}

The results of the three-factor ANOVA for assemblages of phytoplankton sampled seasonally with three replicates at each of four locations in Hervey Bay in 1994 are presented in table 7 .

Seasonal and zone differences are most apparent with some site influence detected. Rhizolsolenia and Guinardia sp. were found in significantly higher concentrations in offshore sites compared to the near shore zone $(\mathrm{P}<0.01)$. Highest concentrations of Guinardia sp. were found in autumn $(\mathrm{P}<0.05)$ compared to summer and spring, with lowest abundance in winter $(\mathrm{P}<0.05)$. Thalassionema nitzschioides, Thalassiosira sp. $\quad(\mathrm{P}<0.01) \quad$ and Pseudonitzschia sp. $(\mathrm{P}<0.05)$ were found in highest abundance at near shore rather than offshore sites. Skeletonema costatum had significantly higher concentrations in autumn than for other seasons $(\mathrm{P}<0.05)$. The results of the ANOVA provide substantial support to multivariate analyses in SIMPER (table 6).

\subsection{ENVIRONMENTAL DETERMINANTS PHYTOPLANKTON ASSEMBLAGE STRUCTURE}

OF

The BIOENV program in PRIMER uses Euclidean distance to measure dissimilarity of environmental variables and the Bray-Cutis coefficient to measure similarity among biotic relationships. The (dis)similarity matrices constructed are used to select the abiotic variable subset that maximises their rank correlation. For Hervey Bay in 1994, of the 23 physicochemical water quality parameters recorded at each survey for each location, the combination of the four water quality parameters $\mathrm{Chl} a$, Secchi depth, SRP and $\mathrm{pH}$ were most strongly linked $(\rho=0.63)$ to seasonal changes of phytoplankton assemblages. Therefore, these four water quality parameters ( $\mathrm{Chl} a$, Secchi depth, SRP and $\mathrm{pH}$ ) are strong determinants of the observed phytoplankton assemblage structure and changes in these parameters are likely to produce changes in phytoplankton density and community structure.

Table 4: Phytoplankton species and group presence, absence and gradients from sites adjacent to nutrient sources in Hervey Bay (site 35; Mary River mouth and site 10; Pulgul Creek).

\begin{tabular}{|c|c|c|c|c|c|c|c|}
\hline Presence only & Site & Absence only & Site & Gradient from siè 35 & Gradient from site 100 & Opposite ercadient flow & $\begin{array}{l}\text { Nutrient sources } \\
\text { Sutites } 108 \text {. }\end{array}$ \\
\hline 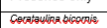 & & 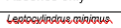 & & 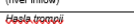 & 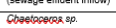 & 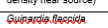 & 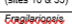 \\
\hline Hastag wewoblase & 35 & 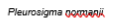 & ${ }_{35}$ & Eseudepitzschis sp. & 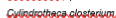 & Gwiprdig stritata & chanbica \\
\hline 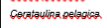 & 2 & 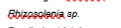 & 10 & 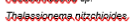 & & 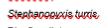 & \\
\hline & & Fragilaria striźtula & 2 & & & & \\
\hline & & 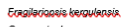 & 2 & & & & \\
\hline & & 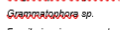 & $2^{2}$ & & & & \\
\hline & & 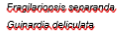 & ${ }_{10}^{16}$ & & & & \\
\hline
\end{tabular}

\subsection{POST FLOOD WATER QUALITY}

AND

\section{PHYTOPLANKTON ASSEMBLAGE STRUCTURE}

Physico-chemical water quality parameters, phytoplankton cell density, number of phytoplankton species and the Shannon diversity index recorded in February 1995 are presented in table 8 . The catchment received $2,783 \mathrm{~mm}$ of rainfall compared to $874 \mathrm{~mm}$ in February 1994. The results for the same sites in February 1994 are presented for comparison.

The effect of the flood in February 1995 produced an increase in Chl $a$ concentration of 11, 17 and 4-fold at Pulgul Creek, the Mary River mouth and the S2 Buoy (sites 
10, 35 and 16, respectively). SRP doubled at site 10, tripled at the Mary River mouth (site 35) but decreased at the S2 Buoy (site 16) while $\mathrm{NO}_{x}$ decreased at Pulgul Creek (site 10) and the S2 Buoy (site 16) but increased by 26 times at the Mary River mouth (site 35). Secchi depth was halved and salinity dropped by $8 \mathrm{ppt}$ and $3 \mathrm{ppt}$ at near and offshore sites respectively. The $\mathrm{pH}$ increased by $0.21,0.08$ and 0.03 units at Pulgul Creek, the Mary River mouth and the S2 Buoy (sites 10, 16 and 35 respectively) and oxygen saturations increased by a greater margin at sites close to nutrient sources, than for more distant sites $(54 \%, 24 \%$ and $9 \%$ respectively at sites 10,35 and 16 ). Redox potential decreased substantially and turbidity approximately tripled at each site. The Mary River mouth (site 35) experienced the greatest impact from the flood event with an increase in diatom diversity from 10 to 38 species and a cell concentration that increased from 38 to 679 cells $/ \mathrm{mL}$.

Phytoplankton cell density (cells $/ \mathrm{mL}$ ) increased by nine, 13 and 18 times at Pulgul Creek, the S2 Buoy the Mary River mouth (sites 10, 16 and 35, respectively) after the flood. It was expected from $\mathrm{Chl} a$ results that the offshore location at the S2 Buoy (site 16) would also have the lowest increase in cell number however, for a factor of four increase in Chl $a$ concentration, an increase in cell density by a factor of 13 was produced. It appears that the cell size and/or species of the phytoplankton found at the S2 Buoy (site 16) following the flood was smaller than the phytoplankton species that increased in number at the other two sites (site 10; Pulgul Creek, site 35; Mary River mouth). The smaller cell size produced a relatively small increase in Chl $a$ concentration but a large increase in cell density. Pulgul Creek (site 10, effluent influenced) had a greater increase in cells greater than $20 \mu \mathrm{m}$, the S2 Buoy (site 16) had a factor of four increase for both cell sizes and the Mary River mouth (site 35, river influenced) had a proportionally greater increase in small cells in the phytoplankton assemblage after the flood.

Table 5: Dominant three phytoplankton species and groups contributing to \% similarity for each site and season in Hervey Bay in 1994 (site 2; Artificial Reef, site 10; Pulgul Creek, Site 16; the S2 Buoy, Site 35; Mary River mouth). Species 'typical' at each site.

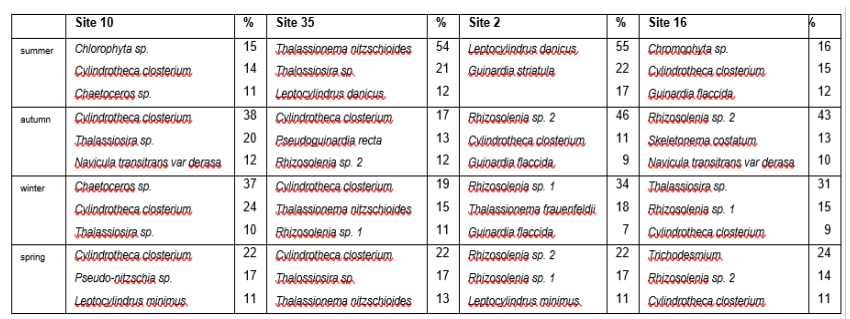

The Chl $a$ increase at the Mary River mouth (site 35) was 17 times greater considering all cell sizes than the February 1994 value, compared to only 10 times greater for the larger phytoplankton species greater than $20 \mu \mathrm{m}$. Cell density at the mouth of the Mary River increased by a factor of 18 following the flood. Diatoms were the main group identified in the samples however dinoflagellates increased by a factor of 29 at the Mary River mouth (site 35) and therefore should be documented.

There was no change in the number of phytoplankton species identified at site 10 however the particular species making up the assemblage structure at this time was dominated by some additional species to what were usually present. Sites 16 and 35 had increases by 8 and 28 diatom species respectively in their phytoplankton assemblages. Table 9 shows the phytoplankton species that were affected by the freshwater, nutrient and sediment input as a result of the flood. The phytoplankton species dominating the assemblages at each site after the flood are presented.

Table 6: Average dissimilarity of phytoplankton assemblages between sites for each season using SIMPER (SD = standard deviation); pink = mimimum, orange $=$ maximum .

\begin{tabular}{|c|c|c|c|c|c|c|c|c|}
\hline & 2 vs 10 & 2 vs 16 & 10 vs 16 & 2 vs 35 & 10 vs 35 & 16 vs 35 & Mean $(\%)$ & $\mathrm{SD}(\%)$ \\
\hline Summer & 87 & 89 & 88 & 85 & 83 & 87 & 86.5 & 2.2 \\
\hline Autumn & 83 & 73 & 88 & 79 & 82 & 76 & 80.2 & 5.3 \\
\hline Winter & 88 & 74 & 84 & 69 & 84 & 75 & 79.0 & 7.4 \\
\hline Spring & 86 & 76 & 91 & 77 & 77 & 82 & 81.5 & 6.0 \\
\hline Axge dissimilarity (\%) & 86 & 78.0 & 88 & 77.5 & 82 & 80 & 81.8 & 4.2 \\
\hline Standard deviation & 1.9 & 6.4 & 2.5 & 5.7 & 2.7 & 4.8 & & \\
\hline
\end{tabular}

C. closterium was a typical diatom species at site 10 (Pulgul Creek WWTP) before the flood (tables 4, 5 and 9) and then bloomed after the flood to 19 times its 1994 cell concentration. Pseudonitzschia sp. and Skeletonema costatum were not recorded at site 10 (Pulgul Creek WWTP) in any great quantity until after the flood and these species increased by 160 and 44 times, respectively. Prior to the flood, site 16 (S2 Buoy) was dominated by Rhizosolenia sp., C. closterium, and Leptocylindrus minimus except for spring (particularly October) when Trichodesmium sp. bloomed.

Table 7: Summary of three factor analyses of variance for selected phytoplankton species in Hervey Bay in $1994(n=3)$. F-ratios in bold calculated after post-hoc pooling at $P>0.25$ (Winer et al., 1991). Data were examined for heterogeneity of variance using Cochran's C-test and were transformed to log $(x+1)$ before analysis (Underwood 1981, 1997); *significant at $P<0.05$, ${ }^{* \star} P<0.01$ ).

\begin{tabular}{|c|c|c|c|c|c|c|c|}
\hline \multirow[b]{2}{*}{ Source of variation } & \multicolumn{3}{|c|}{$\begin{array}{l}\text { Rhizasoleniasp } \\
\mathrm{C}=0.23\end{array}$} & \multicolumn{2}{|c|}{$\begin{array}{l}\text { Skeletonema costatum } \\
\mathrm{C}=0.27\end{array}$} & \multicolumn{2}{|c|}{$\begin{array}{l}\text { Thalassionemg nitzschioides } \\
\qquad \mathrm{C}=0.23\end{array}$} \\
\hline & dff & MS & $F$ & MS & $\mathrm{F}$ & $\mathrm{MS}$ & $\mathrm{F}$ \\
\hline Season & 3 & 5.48 & 8.68 & 3.51 & $20.30^{*}$ & 1.09 & 2.85 \\
\hline Zone & 1 & 20.08 & $10.04^{* *}$ & 0.01 & 0.07 & 7.53 & 1.05 \\
\hline Site & 1 & 16.72 & $8.36^{* \star *}$ & 0.14 & 0.49 & 4.06 & 3.01 \\
\hline Sex Zo & 3 & 0.27 & 0.14 & 0.22 & 0.77 & 0.80 & 0.49 \\
\hline $\mathrm{Se} \times \mathrm{Si}$ & 3 & 0.63 & 0.32 & 0.17 & 0.63 & 0.38 & 0.28 \\
\hline Zox Si & 1 & 6.73 & & 0.10 & 0.37 & 7.20 & $5.24^{*}$ \\
\hline \multirow{3}{*}{ Residual } & 3 & 0.36 & & 0.29 & 1.03 & 1.65 & \\
\hline & 32 & 2.01 & & 0.28 & & 1.35 & \\
\hline & & \multicolumn{2}{|c|}{ 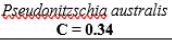 } & \multicolumn{2}{|c|}{$\begin{array}{l}\text { Guinardia sp. } \\
\mathrm{C}=0.17\end{array}$} & \multicolumn{2}{|c|}{$\begin{array}{c}\text { Thalassiosira sp. } \\
C=0.19\end{array}$} \\
\hline Source of variation & df & MS & $\mathbf{F}$ & MS & $F$ & MS & $F$ \\
\hline Season & 3 & 1.12 & $3.49^{*}$ & 2.38 & $11.88^{*}$ & 0.15 & 0.12 \\
\hline Zone & 1 & 4.74 & 2.64 & 12.67 & $24.75^{* *}$ & 7.83 & $11.76^{* *}$ \\
\hline Site & 1 & 0.15 & 0.47 & 6.45 & $12.59^{* \star}$ & 0.19 & 0.28 \\
\hline Sex Zo & 3 & 1.85 & $5.76^{\star}$ & 0.56 & 1.10 & 2.10 & 1.01 \\
\hline $\mathrm{SexSi}$ & 3 & 0.40 & & 0.20 & 0.39 & 1.30 & 1.06 \\
\hline $\mathrm{ZoxSi}$ & 1 & 1.79 & & 0.51 & & 0.11 & \\
\hline $\mathrm{Se} \times \mathrm{ZoxSi}$ & 3 & 0.52 & $5.59^{*}$ & 0.42 & & 2.08 & $3.13^{*}$ \\
\hline Residual & 32 & 0.30 & & 0.52 & & 0.68 & \\
\hline
\end{tabular}

After the flood Bacteriastrum furcatum, Rhaphoneis amphiceros, Leptocylindrus danicus and Guinardia flaccida were dominant offshore at the S2 Buoy (site 16). 
The cells typical after the flood were much smaller than the Rhizosolenia sp. which usually dominates site 16 and this may explain the disproportionate increase in $\mathrm{Chl} a$ concentration relative to the increase in cell density. This finding indicates that $\mathrm{Chl} a$ concentration is species dependent and as such is not an accurate indicator of the trophic state of a water body.

The impact of the 1995 flood on the water quality and species composition of phytoplankton in Hervey Bay provides valuable information to management authorities upon which to base decisions for the timing of terrestrial activities. Dredging and other terrestrial activities such as construction may impact water quality and should therefore be scheduled outside of flood periods. In addition, fishing and recreational activities should be avoided for a period following a flood to ensure the health and safety of swimmers and aquatic species exposed to toxic diatom species $[8,10,13,25,36]$.

\subsection{HERVEY BAY COMPARISON ANZECC/ARMCANZ TRIGGER VALUES}

TO

Table 10 presents the default trigger values for water quality targets listed by ANZECC/ARMCANZ [15] for concentrations of key indicators, above or below which there is a risk of adverse biological effects. The table also presents the maximum values measured for these indicators at each of the nine sites during 1994 in preference to the annual mean values presented in figure 4 . The maximum values are most important and more relevant as phytoplankton blooms occur in a matter of days, as seen by the flood data in the present study and those previously documented $[42,43,44]$. The impact can be intense, with blooms reacting to increased nutrient supply and consequently decreasing light availability and/or producing toxins within days, with the potential to result in devastating effects to habitats, plants and animals (i.e. coral, seagrass, fish, prawns, dugongs and whales) in Hervey Bay.

Table 8: Comparison of water quality parameters at three sites in Hervey Bay (Pulgul Creek, site 10; the S2 Buoy, site 16 and the Mary River mouth, site 35) in February 1994, compared to February 1995, following a flood and cyclone.

\begin{tabular}{|c|c|c|c|c|c|c|c|c|c|c|c|c|c|c|}
\hline Site & $\begin{array}{l}\text { Year } \\
\text {. }\end{array}$ & $\begin{array}{l}\text { Clal' 'a' } \\
\text { (ugl) }\end{array}$ & $\begin{array}{l}\text { Cells } / \mathrm{mL} \\
=20 \mathrm{um}\end{array}$ & $\begin{array}{c}\text { Secchi } \\
(\mathrm{m})\end{array}$ & \multicolumn{2}{|c|}{$\begin{array}{c}\text { SRP NOX } \\
(\mu g / L)\end{array}$} & $\begin{array}{l}\text { Temp } \\
\left({ }^{\circ} \mathrm{C}\right)\end{array}$ & $\mathrm{pH}$ & $\begin{array}{l}\text { Salinity } \\
(\mathrm{ppm})\end{array}$ & $\% \mathrm{O}_{2}$ & $\begin{array}{l}\text { Turbidity } \\
\text { (NTU) }\end{array}$ & $\begin{array}{l}\text { Density } \\
\text { cells }\end{array}$ & $\begin{array}{l}\text { diatom } \\
\text { \# sp. }\end{array}$ & $\begin{array}{l}\text { Shannon } \\
\text { Index }\end{array}$ \\
\hline \multirow[t]{2}{*}{10} & 1994 & 1.25 & 0.54 & 1.3 & 4.5 & 4.0 & 26.6 & 8.07 & 33.1 & 100.7 & 2.70 & 38 & 23 & 2.3 \\
\hline & 1995 & 11.2 & 8.5 & 0.6 & 9.0 & 3.0 & 30.2 & 8.38 & 24.8 & 154.6 & 7.20 & 336 & 23 & 1.6 \\
\hline \multirow[t]{2}{*}{16} & 1994 & 0.28 & 0.19 & 7.9 & 4.3 & 13.0 & 26.9 & 8.16 & 37.2 & 111.9 & 0.59 & 19 & 19 & 2.2 \\
\hline & 1995 & 1.30 & 0.73 & 3.1 & 3.0 & 1.0 & 26.0 & 8.24 & 34.4 & 121.1 & 1.36 & 253 & 27 & 2.9 \\
\hline \multirow[t]{2}{*}{35} & 1994 & 1.00 & 0.39 & 24 & 4.0 & 2.0 & 26.8 & 8.16 & 36.8 & 101.0 & 1.80 & 38 & 10 & 2.1 \\
\hline & 1995 & 17.4 & 3.7 & 1.8 & 12.0 & 58.0 & 23.4 & 8.19 & 28.3 & 125.7 & 6.26 & 679 & 38 & 3.1 \\
\hline
\end{tabular}

The maximum annual values for $\mathrm{Chl} a$ and $\mathrm{pH}$ at all sites are below the default trigger values suggested by ANZECC/ARMCANZ [15] for estuaries. Site 10 is the only site above the trigger value set for SRP and turbidity. The $\mathrm{NO}_{\mathrm{x}}$ values at sites 35 and 18 are elevated above the trigger value and all sites except site 34 , are above the trigger value set for $\mathrm{NH}_{4}{ }^{+}$. Dissolved oxygen is above the trigger value set at all sites surveyed in Hervey Bay. The values for these parameters during the flood (signified by $*$ in table 12 ) are
3 to 6 times the trigger values set for $\mathrm{Chl} a$ at sites 10 and 35 respectively. Findings show that a revision and reduction of trigger and threshold values recommended by government for water quality parameters, is required.

\section{DISCUSSION}

\subsection{PHYTOPLANKTON AS BIOINDICATORS}

Estuaries and coastal zones contain a diverse range of critical habitats that support maritime, recreational and commercial activities that are often directly or indirectly related to tourism and the economy of coastal towns and cities. Improved understanding of the differences and links between the parameters operating within these systems is paramount to their efficient management and ultimate health.

Results of the present study showed that the water quality gradient established from near shore nutrient sources at the Mary River and Pulgul Creek to offshore zones in Hervey Bay supported significantly different assemblages of phytoplankton within each zone. However, differences were not consistent across zones or seasons. In addition, phytoplankton assemblage structure at four locations within the near and offshore zones were linked to the water quality parameters Chl $a$, Secchi depth, SRP and $\mathrm{pH}$ that characterised each location.

Table 9: Phytoplankton species and groups most affected by February 1995 flood with increased nutrient, sediment and freshwater input. Characteristics of the phytoplankton assemblage structure in February 1994 (cells/mL) at Pulgul Creek (site 10), the S2 Buoy (site 16) and the Mary River mouth (site 35) were compared to February 1995 to assess changes in the community structure and the presence of toxic species.

\begin{tabular}{|c|c|c|c|c|c|c|c|}
\hline Species & Site & 1994 & 1995 & Species & Site & 1994 & 1995 \\
\hline culiadrotheca ciosteriwm & 10 & 34.0 & 648 & Cerataulina bicomis, & 35 & 0.3 & 109 \\
\hline Eseudopitzschia sp. & 10 & 2.0 & 320 & Stepbanopuxis turisa & 35 & 1.0 & 105 \\
\hline Skeletopema costatum & 10 & 1.2 & 53 & Detooula cooferkaceale & 35 & 1.0 & 73 \\
\hline Roperia tessejata & 10 & 0.0 & 53 & Gujioardia striata & 35 & 1.0 & 70 \\
\hline Nitzschia sicula var. sigula & 10 & 0.2 & 34 & Skeletopema costatum & 35 & 1.2 & 66 \\
\hline Chlorophyta & 10 & 3.3 & 29 & Roperia tesselata & 35 & 1.3 & 66 \\
\hline Qitzsschia bifurcate & 10 & 0.0 & 28 & Gujoardia flaccida & 35 & 1.5 & 56 \\
\hline Chaetoceros sp. & 10 & 19.0 & 18 & chaetoceros socialis & 35 & 0.5 & 44 \\
\hline Bacillenia paxilitera & 10 & 0.1 & 16 & Lentocylindrus danicus & 35 & 8.0 & 41 \\
\hline Thalassigsica sp. & 10 & 8.0 & 16 & Thalassiosica so. & 35 & 6.0 & 40 \\
\hline Leptocylindrus mivipus & 10 & 4.4 & 13 & chaetoceros atianticus & 35 & 0.5 & 33 \\
\hline Mitzschia pandiupoiformis & 10 & 0.0 & 13 & Hepiaulus membranaceus & 35 & 0.3 & 30 \\
\hline Stephanopuxis palperiana & 10 & 1.3 & 13 & Bacteriastrum furcatum & 35 & 0.5 & 27 \\
\hline Bacteriastrum furcatum & 16 & 2.3 & 39 & chaetoceros teres & 35 & 0.3 & 24 \\
\hline Rhaphoneis amphiceros & 16 & 0.1 & 22 & Rseudopitzsschia sp. & 35 & 3.0 & 17 \\
\hline Guipardia striata & 16 & 1.5 & 15 & chaetoceros radicans & 35 & 3.0 & 17 \\
\hline Leptocylindrus daaicus, & 16 & 2.0 & 15 & Chaetoceros sp. 3 (wide) & 35 & 2.0 & 16 \\
\hline Gujoardia flaccida & 16 & 2.7 & 14 & Rseuddonitzschia seviata $f$ seriata & 35 & 0.4 & 16 \\
\hline Thalassionempa trauenteldili & 35 & 4.3 & 156 & Delobinejs surcilloides. & 35 & 0.3 & 15 \\
\hline Dinoflagellates & 35 & 4.0 & 116 & Nitzschia braarudi & 35 & 0.4 & 14 \\
\hline
\end{tabular}

The present study supports observations by others $[29,26]$ that diatoms generally dominate the structure of phytoplankton assemblages in near and offshore marine zones. Comparison of individual taxa in the present study found significant zone differences for the diatoms Rhizosolenia sp., Guinardia sp., Thalassionema nitzschioides and Thalassiosira sp. that indicates their potential application as indicators and discriminators of particular habitats, environmental health or status. 
Multivariate tests (SIMPER) also indicated the diatom species Cylindrotheca closterium, Chaetoceros sp., Haslea trompii, Cerataulina sp. and Leptocylindrus danicus as indicators with the potential for further investigation as indicators in other estuaries.

The findings of the present study are supported by a recent study that identified Skeletonema costatum, Cylindrotheca closterium and Cyclotella choctawhatcheeana responding regularly to enhanced nutrient concentrations in coastal areas on a seasonal basis [26]. The flood event at the conclusion of field data collection in Hervey Bay provided a unique opportunity to assess the effect of increased nutrient and sediment input on phytoplankton density, distribution and assemblage structure within the Hervey Bay system. The phytoplankton species and groups with the largest response to this nutrient input, mainly SRP, included Cylindrotheca closterium, Pseudonitzschia sp. and Skeletonema costatum at Pulgul Creek (site 10; treated sewage effluent disposal site) and Thalassionema frauenfeldii, dinoflagellates and Cerataulina bicornis at the mouth of the Mary River, where both SRP and $\mathrm{NO}_{\mathrm{x}}$ experienced a substantial increase. Toming and Jaanus [26] also found different responses of particular phytoplankton species to preferred nutrients.

Table 10: Government "trigger values" for water quality in marine and estuarine (bracket) systems were exceeded by the maximum annual values of key water quality parameters and bioindicators recorded in Hervey Bay in 1994. * flood values in February 1995

\begin{tabular}{|c|c|c|c|c|c|c|c|}
\hline & Cobla ( $\mu g / L)$ & $\operatorname{SRP}(\mu / L)$ & $\mathrm{NO}_{x}(\mu \mathrm{g} / \mathrm{L})$ & $\mathrm{NH}_{4}^{+}(\mu \mathrm{g} / \mathrm{L})$ & $\mathrm{DO}(\%)$ & $\mathrm{pH}$ & Turbidity (NTU) \\
\hline Value & $1(1.5)-4(5)$ & $5(15)-10$ & $5-15$ & 15 & $80-110 \%$ & $7.0-8.5$ & $0.5-10$ \\
\hline Site 10 & $\begin{array}{ll}{ }^{* 11.2} & 4.7\end{array}$ & $\begin{array}{ll}9.0 & 15.5 \\
\end{array}$ & ${ }^{* 3.0}$ & $\begin{array}{ll}{ }^{*} 6.0 & 31 \\
\end{array}$ & *154.6 114 & $\begin{array}{ll}8.38 & 8.07\end{array}$ & $\begin{array}{ll}7.2 & 10.7\end{array}$ \\
\hline Site 35 & $\begin{array}{ll}* 17.4 & 2.8\end{array}$ & $\begin{array}{ll}{ }^{2} 12.0 & 14\end{array}$ & 58 & $\begin{array}{ll}* 9.5 & 18\end{array}$ & *125.7 122 & 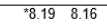 & $\begin{array}{ll}{ }^{*} 6.26 & 8.5\end{array}$ \\
\hline Site 5 & 1.8 & 6 & 1 & 21 & 119.8 & 8.04 & 3.6 \\
\hline Site 30 & 1.7 & 6 & 8 & 37 & 115 & 8.16 & 3.1 \\
\hline Site 2 & 0.9 & 4 & 5 & 38 & 113 & 8.21 & 2.8 \\
\hline Site 16 & ${ }^{*} 1.3$ & $\begin{array}{ll}{ }^{3} 3.0 & 4.3 \\
\end{array}$ & ${ }^{*} 1.0$ & ${ }^{2} 6.5 \quad 20$ & ${ }^{*} 121.1122$ & $\begin{array}{ll}{ }^{8} 8.24 & 8.16\end{array}$ & ${ }^{* 1.36}$ \\
\hline Site 17 & 0.3 & 4 & 5 & 16 & 128 & 8.21 & 0.4 \\
\hline Site 18 & 0.5 & 4 & 18 & 62 & 127 & 8.23 & 1.6 \\
\hline Site 34 & 1.2 & 3 & 1.4 & 12 & 116 & 8.22 & 2.8 \\
\hline
\end{tabular}

Thus, these phytoplankton species are further supported as reliable bio-indicators in terms of eutrophication by an unrelated study in the Baltic Sea. As noted by John [7], the relatively high universality of diatom species makes them ideal bio-monitors at the regional, national and international level. In addition, the potential of diatoms to preserve in the fossil record makes them ideal bio-indicators of change over geological time and therefore have valid application to studies in climate change, nutrient status and habitat health in the recent past and historical trophic environments.

\subsection{WATER QUALITY TRENDS AND TRIGGER VALUES}

The results from the principal component analyses (PCA) (Figure 6) show a clear geographical basis to the water quality from sites close to point sources to off shore sites with $73 \%$ of the variability in the original 14 parameters, captured in a 2-dimensional plot. Correlations between Chl $a$ and SRP (Pearson correlation coefficient, $\mathrm{r}=0.64, \mathrm{P}=$ 0.066, $\mathrm{n}=9)$, and Chl $a$ and TSS, $(\mathrm{r}=0.79, \mathrm{P}=0.014, \mathrm{n}=$ 9) were prominent for annual mean values measured along

the water quality gradient. Chl $a, \mathrm{SRP}, \mathrm{NO}_{\mathrm{x}}, \mathrm{TSS}$ and turbidity decreased and Secchi depth increased, an indication of improved water quality, with distance offshore. Rainfall often preceded peaks in nutrient concentrations and reduced water clarity however, not all changes were linked with local or regional rainfall. Alternate sources of nutrients in the area included treated sewage effluent and untreated discharge from commercial whale watching and fishing vessels that may contain holding tanks but neglect to pump out at the correct facility.

Trigger values suggested by ANZECC/ARMCANZ [15] for some key water quality parameters as indicators of environmental health, were in excess for SRP at Pulgul Creek (site 10) and the Mary River mouth (site 35), for turbidity at Pulgul Creek (site 10) and for $\mathrm{NO}_{\mathrm{x}}$ at the Outer Banks (site 18) and the Mary River mouth (site 35). Eight sites were above the trigger values set for $\mathrm{NH}_{4}{ }^{+}$and all sites were in excess for dissolved oxygen. Chl $a$ concentration was below trigger values even during bloom events. For the purposes of the present study a bloom indicates a sharp rise in phytoplankton cell concentration that is clearly visible on the water surface but that is not necessarily associated with any adverse effects. A bloom of Trichodesmium occurred in the offshore zone in Hervey Bay in October 1994 and although a cell density of 242 cells $/ \mathrm{mL}$ was recorded, the Chl $a$ level was $0.8 \mu \mathrm{g} / \mathrm{L}$ and below the suggested value for a marine or estuary (range of between 1.0 and $5.0 \mu \mathrm{g} / \mathrm{L}$ ). Once again, results show the need for reduced trigger values suggested by government. Neither a decrease in Secchi depth or elevated nutrient levels was observed. This indicates elevated 'trigger' level for Chl $a$ and the need for cell counts in preference to $\mathrm{Chl} a$ measurement when assessing the status of phytoplankton in the water column.
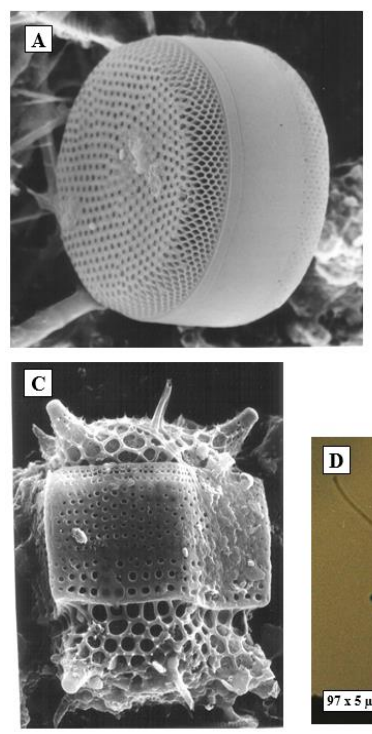

Figure 11: Light and scanning electron micrographs used to identify some phytoplankton species (A:Coscinodiscus sp., B and C: Odontonella sp., D: Cylindrotheca closterium and E: Pseudonitzschia sp.

Following the flood in February 1995 phytoplankton cell density increased from 38 to 679 cells $/ \mathrm{mL}$ at the Mary 
River mouth (site 35) with an associated increase in SRP from 4.0 to $12.0 \mu \mathrm{g} / \mathrm{L}$ and a decrease in Secchi depth from 2.4 to $1.8 \mathrm{~m}$. It is surprising that the post flood water quality values for $\mathrm{SRP}, \mathrm{NO}_{\mathrm{x}}$ and $\mathrm{NH}_{4}{ }^{+}$at all sites in February 1995 , except $\mathrm{NO}_{\mathrm{x}}$ at site $35,3.5 \mathrm{~km}$ from the mouth of the Mary River, were below the annual maximums recorded during 1994 and below the trigger values set by ANZECC/ARMCANZ [15]. Disruption to sediment processes may explain the reduction in $\mathrm{NH}_{4}{ }^{+}$after the flood. Turbidity values recorded during the flood were below the trigger values set for this region while Chl $a$ values were up to 6 times the 1994 maxima and three times greater than the default trigger value set for an estuary. The observed increase in Chl $a$ to exceed the 'trigger value' without an accompanying excess by other water quality parameters such as nutrient concentrations and turbidity, indicates that a revision and reduction to the thresholds for these parameters is necessary.

In addition, the bloom of Trichodesmium at the S2 Buoy (site 16) in October 1994 and some diatom species in February 1995 did not increase the Chl $a$ concentration to a value above the trigger values set for this region. This also indicates that an adjustment to the trigger values is necessary. Indeed, if the trigger value for Chl $a$ were set to $1.0 \mu \mathrm{g} / \mathrm{L}[45]$ as has been done for Moreton Bay, then most stations would have exceeded this suggested value.

These findings indicate that, in order to account for a range of environmental conditions that may be precursors to phytoplankton blooms, trigger values set for some water quality parameters (e.g. Chl $a$ and nutrient concentrations, and turbidity) are elevated, ineffective and in need of reduction. Further assessment for other estuaries is also required during dry and wet periods in order to set values that provide a real warning to signify those times that should be more carefully monitored.

\subsection{TRENDS IN PHYTOPLANKTON ASSEMBLAGE STRUCTURE}

Univariate diversity indices calculated for 150 phytoplankton species identified at four sites showed the phytoplankton assemblages followed a similar pattern of seasonal change for evenness and diversity (Appendix G). Species richness (S) calculated for nine sites showed that the two near shore, nutrient source sites and the two most offshore sites followed a similar seasonal trend with greater change observed in phytoplankton assemblages between seasons than the other sites. The five sites located geographically between these four locations, were more consistent in species diversity and showed less fluctuation in assemblage structure between seasons. This may be due to less extreme fluctuations in the water quality parameters that may influence phytoplankton assemblage structure at intermediate zones. The parameters include nutrient concentration (SRP) and light attenuation (Secchi depth, TSS and turbidity) and $\mathrm{pH}$ determined in the present study by BIO-ENV in PRIMER and salinity [46,26], water temperature [47,26], trace elements [48] and carbonate [49] determined by others to influence phytoplankton succession and growth.

\subsubsection{NUTRIENT LIMITATION}

The multivariate statistical analyses (figures 9 and 10) revealed both seasonal and site differences between the phytoplankton assemblages. Agglomerative hierarchical clustering showed a seasonal component to the seasonal phytoplankton differences and non-metric multidimensional scaling performed on seasonal phytoplankton species lists for four sites, revealed that site differences were apparent. This conclusion is supported by the ANOSIM2 analyses. Chl $a$, Secchi depth, SRP and pH were found to be the best water quality parameter subset to maximise the rank correlation with the phytoplankton assemblages $(\rho=0.63)$ and hence best link the water quality at these sites to changes in assemblage structure.

It is noted though that these correlations should not be misinterpreted as cause and result relationships. For example, with respect to nutrient limitations, one should not interpret the SRP relationship as an indicator of SRP limitation (i.e. one should not suggest that the higher the phytoplankton biomasses are caused by the higher SRP concentrations). In this respect it is possible that, as was found for Moreton Bay, the higher SRP concentrations merely represented an indicator for Waste Water Treatment Plant (WWTP) discharges (i.e. the higher the SRP concentration the higher the proportion of the collected water was WWTP discharge). With respect to such results, one can conclude that some component of the WWTP discharge caused the higher phytoplankton and hence higher Chl $a$ concentration. For Moreton Bay, it was demonstrated by experiment [50] and modelling [45] studies that this limiting component was dissolved inorganic nitrogen (DIN).

Similarly, in Hervey Bay following the flood (tables 8, 9, 10 and 11), the greatest increase in phytoplankton cell density was recorded at the Mary River mouth (site 35; 38 to 679 cells $/ \mathrm{mL}$ ) where although an increase in SRP was recorded (4.0 to $12.0 \mu \mathrm{g} / \mathrm{L})$ the proportional increase in $\mathrm{NO}_{\mathrm{x}}$ was far greater $(2.0$ to $58 \mu \mathrm{g} / \mathrm{L}$ ). At Pulgul Creek (site 10) however, the increase in cell density was half that of the Mary River (38 to 336 cells $/ \mathrm{mL}$ ) with an increase in SRP (4.5 to $9.0 \mu \mathrm{g} / \mathrm{L})$ but a decrease in $\mathrm{NO}_{\mathrm{x}}(4.0$ to $3.0 \mu \mathrm{g} / \mathrm{L})$. This finding provides support to those of Dennison et al. [20] and Bell et al. [45] for Moreton Bay in that with excess $\mathrm{NO}_{\mathrm{x}}$ availability in the Hervey Bay system at the Mary River, phytoplankton growth exceeded that of the Pulgul Creek site to suggest that $\mathrm{NO}_{\mathrm{x}}$ may also be the limiting component for phytoplankton growth in Hervey Bay. Toming and Jaanus [26] found that different phytoplankton species respond best to various combinations of DIP, DIN, TP and TP. Further studies directed at isolating the effects of these nutrient components on phytoplankton within the Hervey Bay system are required. 


\subsubsection{INDICATOR AND DISCRIMINATOR SPECIES}

The phytoplankton composition (table 3) show that diatoms dominated for all sites and seasons, making up to between $58 \%$ and $97 \%$ of the species structure. Chaetoceros sp. and Cylindrotheca closterium concentrations formed a gradient coincident with water quality from Pulgul Creek into Hervey Bay and Haslea trompii, Pseudonitzschia sp. and Thalassionema nitzschioides concentrations formed a gradient with distance from the Mary River mouth into Hervey Bay. Phytoplankton species typical of survey sites were identified as 'indicators' and those species that discriminated the sites based on dissimilarity of phytoplankton assemblages, were identified as 'discriminators' using a SIMPER analysis (PRIMER v5, 31].

C. closterium dominated the seasonal phytoplankton assemblages at nutrient source sites and as a result, identifies the diatom $C$. closterium as a pollution indicator. This hypothesis is given support by a recent study that found the diatoms Cylindrotheca closterium, Skeletonema costatum, and Cyclotella choctawhatcheeana showed a strong positive relationship with coastal nutrient concentrations and suggested these species as potential reliable indicators of eutrophication [26]. Rhizosolenia sp. and the Guinardia species G. flaccida and G. striatula, were indicators for the offshore relatively pristine sites, which conversely may determine these species as indicators of environmental health in this waterway.

It is important to note that some phytoplankton species are nitrogen fixers and do not need DIN or other nongaseous forms of nitrogen such as organic $\mathrm{N}$ to grow. This has been demonstrated for the cyanobacterium Trichodesmium sp. [50,51] and for Lyngbya majuscula, where growth is stimulated by phosphate and iron chelating agents [52]. The authors hypothesise that if $\mathrm{N}$ load reduction occurs without $\mathrm{P}$ load reduction from WWTP's, that increased growth of these phytoplankton species and other diazotrophs ( $\mathrm{N}$ fixing bacteria) may occur.

Algal blooms of the cyanobacteria Trichodesmium sp. and of the diatoms Cerataulina sp., Leptocylindrus danicus and Cylindrotheca closterium were identified during 1994, a relatively 'dry' year. The Trichodesmium bloom was obvious from the surface however was not evident from Chl $a$ concentration. This disparity emphasises the need for cell counts and species identification in preference to measuring Chl $a$ and/or sizing phytoplankton alone. Following the flood in February 1995, the toxic diatom species Pseudonitzschia sp. bloomed together with Cylindrotheca closterium, Thalassionema frauenfeldii and a dinoflagellate species.

Blooms of Trichodesmium sp. were identified at site 16 in spring 1994 and are not only responsible for increased light attenuation but are implicated in the irritation of skin and mucous membranes suffered by people swimming along tropical coastlines and in other cases for poisoning of cattle, dogs and occasionally humans [34]. Trichodesmium is an aquatic, $\mathrm{N}_{2}$ fixing cyanobacteria and although it is sometimes referred to as "blue-green algae" they are relatives of bacteria, not eukaryotes.

Several dead and unhealthy dugongs were identified in Hervey Bay in 1994 with skin lesions and necrosis of unidentified origin. The autopsy revealed an invasion by the parasitic protozoan, Cryptosporidium but whether this was the primary or secondary infection was not established [54]. This parasite is very rarely found in the marine environment and is usually restricted to terrestrial animals, birds and fresh to brackish water organisms. Cryptospiridosis is usually spread by eating contaminated food and has been associated with sewerage outfalls [55].

The algal bloom of the cyanobacteria Trichodesmium highlights the need to assess phytoplankton assemblages to species level, if possible, rather than reducing the information to merely a $\mathrm{Chl} a$ concentration, size class or measuring the biomass of diatoms only. The phytoplankton species which are toxic and therefore a real and imminent threat to the aquatic ecosystems may be diatoms, dinoflagellates and/or coccoliths. Therefore, all phytoplankton species must be identified and quantified to enable the best assessment of the water body in question.

The cell concentrations at which harmful algae can become toxic is very species specific and for some species, this level may be only 500 cells/L, or 0.5 cells/mL [56]. The size of toxic cells is also important in that bigger cells contain more toxin than smaller cells. Trichodesmium sp. is a relatively large phytoplankton species and bloomed at 73.3 cells $/ \mathrm{mL}$ or 73,300 cells/L at site 16 in October 1994 in Hervey Bay. This bloom did not coincide with a rainfall event but occurred in an area where whale watching vessels frequent at this time of year. The number of passengers in 1994 was not as great as it is now. Results of this study indicate that the large tidal amplitude and apparent mixing of the water column in Hervey Bay, may not be sufficient to disperse this effluent.

Some dinoflagellates and cyanobacteria can move up and down in the water column, using their opposing pair of flagella in the case of dinoflagellates, and by the expansion and contraction of gas vacuoles and stored weight carbohydrates (i.e. ballast) in the case of cyanobacteria [56]. This allows them to be in the best position to obtain nutrients (often at night) and light (usually during the day on the surface) and to avoid surface water currents that might move them to less favourable places in the water body. Reduced freshwater inflows to coastal waterways due to human intervention is likely to increase the incidence of bloom-forming species by reduced flushing rates and hence increased residence times [32,38].

Bloom formation requires at the most basic level that net algal growth exceeds hydraulic residence time [39]. Hervey Bay is defined as a largely unmodified, tide dominated estuary with a tidal amplitude of $2.4 \mathrm{~m}$ and is therefore considered macrotidal [40]. The mixing that occurs in the water column must be, at times, inadequate and the residence times long enough, so that blooms can in fact occur in Hervey Bay. 
The blooms identified are the result of complex interactions between nutrient loads entering Hervey Bay and their numerous hydrological, physical, chemical and biological fates. To explain and predict these is beyond the means of even the most powerful statistical analyses and most advanced computer technology. The bottom line is that if blooms do occur, then the nutrient loads are above the level (threshold, trigger or otherwise) that a particular system can handle, cope with or accommodate. This finding indicates that action is required in order to effectively reduce the nutrient loads that can be easily controlled (i.e. point sources).

The upgraded sewage treatment plants at Pulgul Creek and Eli Creek in Hervey Bay no longer release treated effluent into the creeks but use it for watering gardens and golf courses. This improvement is one that should be followed by councils in other areas as a means to controlling the nutrient inputs into the marine environment. The control or reduction of diffuse sources of nutrient input to the Hervey Bay system however, is far more difficult to achieve.

The site separation illustrated for water quality in the PCA in figure 6 and for the phytoplankton assemblage structure in the MDS in figure 10, clearly links the water quality of a particular habitat in Hervey Bay to the community structure of the phytoplankton at that location. Further, the water quality parameters responsible for the links are identified as Chl $a$, Secchi depth, SRP and pH. In addition, some phytoplankton "indicator" species that identify nutrient point sources (Fragilariopsis rhombica) and differentiate river (site 35; Haslea trompii, Pseudonitszchia sp.) from WWTP discharges (site 10; Chaetoceros sp., Cylindrotheca closterium) are listed in tables 4. Species diversity and seasonal dominance of particular phytoplankton species is apparent and listed in tables 5 which summarises the results of the multivariate statistical analyses that identify and quantify seasonal changes.

Multivariate methods of analysis are very sensitive for detecting differences between communities and are not in themselves measures of community stress. Diversity does not behave consistently or predictably in response to environmental stress. Theory $[60,61]$ and empirical observation [62] suggest that increasing levels of disturbance may either increase or decrease diversity, or it may remain the same [30].

Results identify and reflect for the first time, the fluid nature and seasonal trends of water quality and phytoplankton dynamics in Hervey Bay and the Great Sandy Straits. They illustrate the importance of measuring any parameter used to define a system often enough to identify seasonal changes and the impact of flooding. The results also demonstrate clearly the futility of measuring physico-chemical water quality parameters twice a year without the response of a biological indicator to place those results in context. A power analysis would be useful to define how frequently to sample and how many replicates are required.

Ecosystem health is defined by its biodiversity, stability and resilience to change [63]. The microscopic size and position in the food chain of phytoplankton offers an ideal medium to observe changes in biodiversity in response to changes in environmental health. The results of this study show that phytoplankton community structure is a good bio-indicator of environmental health which reflects change at the stage where the change is apparent and meaningful but perhaps not yet detrimental or irreversible at the macroscopic or ecosystem level.

\section{CONCLUSION}

A water quality gradient identified from near to offshore sites in Hervey Bay was defined by nutrient concentrations, Chl $a$, light attenuation and phytoplankton community structure. Results show that phytoplankton diversity is a sensitive indicator of ecosystem health. The assemblage response time, as indicated by the February 1995 flood data, provides valuable information on the chemical and physical stressors that influence the Hervey Bay system, that would not be apparent from 'spot' analyses of a variety of physico-chemical water quality parameters.

Correlations between $\mathrm{Chl} a$ and both SRP and total suspended solids were revealed. Diatoms dominated the phytoplankton community structure with seasonal and site differences among 150 species. Chl $a$, Secchi depth, SRP and $\mathrm{pH}$ linked water quality and phytoplankton density and diversity. Indicator species include Cylindrotheca closterium for the nearshore degraded sites and Rhizosolenia sp. and Guinardia sp. (G. flaccida and $G$. striatula) for the offshore more pristine habitats. Following the flood in February 1995, Cylindrotheca closterium, Pseudonitzschia sp. and Skeletonema costatum bloomed at Pulgul Creek (WWTP), and Thalassionema frauenfeldii, Cerataulina bicornis and dinoflagellates bloomed at the the Mary River, where both SRP and oxides of nitrogen $\left(\mathrm{NO}_{\mathrm{x}}\right)$ experienced a substantial increase.

This study demonstrates that some trigger values and water quality targets were exceeded in the dry and flood periods for the macro tidal dominated system and therefore require reduction to prevent adverse impacts to the plant and animal species that inhabit Hervey Bay.

Blooms of Trichodesmium sp. in spring reflect an additional source of nutrients into Hervey Bay, other than those derived from mainland point sources. A likely alternative source being the untreated effluent discharged from whale watching and other commercial vessels. Results provide an intensive and extensive data set for Hervey Bay that satisfies a research need identified by Radke et al. [64] in the report on "Chlorophyll ' $a$ ' concentration".

Flood impacts highlight the need to schedule dredging, construction and other land management activities outside of flood periods. Commercial fishing and swimming should be avoided following a flood due to health risks associated with toxic phytoplankton species (HAB's) and for the 
health and safety of swimmers, consumers and other aquatic species.

The ecological state of Hervey Bay was compromised between 1992 and 1995 and comparative research to reevaluate its current status, would provide valuable insight into the long-term positive impact of changes that have occurred in Hervey Bay over the past 30 years. These include (1) improved sewage treatment to avoid discharge of effluent into Hervey Bay, (2) enforced pumping out of commercial whale watch vessels' holding tanks into approved facilities (3) increased population and (4) modified land practices and management techniques implemented to reduce nutrient and sediment loads from point sources into Hervey Bay. Further investigation and application of the bioindicators of ecosystem health identified in Hervey Bay in the current study, should also be explored in other estuaries.

\section{REFERENCES}

1. Preen, A, Lee Long, WJ and Coles, RG 1995. Flood and cyclone related loss, and partial recovery, of more than $1000 \mathrm{~km}^{2}$ of seagrass in Hervey Bay, Queensland, Australia. Aquat. Bot. 52(1-2): 3-17 https://doi.org/10.1016/0304-3770(95)00491-H

2. Smith, CS, Heggie, D and Radke, LC 2001 In: Conceptual Models of Australian Estuaries and Coastal Waterways. http://www.ozestuaries.org/conceptual_mods/cm_intro.html

3. Choudhury, AK, Das, M, Philip, P and Bhadury, P 2015 An Assessment of the Implications of Seasonal Precipitation and Anthropogenic Influences on a Mangrove Ecosystem Using Phytoplankton as Proxies. Estuar Coasts 38: https://www-jstor-org.ezproxy.slq.qld.gov.au/stable/44851511

4. Zann, LP 1995. Our sea, our future. Major findings of the State of the Marine Environment Report for Australia, Department of the Environment, Sport and Territories, Canberra. https://hdl.handle.net/11017/226

5. National Research Council 2000. Clean Coastal Waters: Understanding and reducing the effects of nutrient pollution. National Academy Press, Washington, DC, USA: 405 pp. https://doi.org/10.17226/9812

6. Bell, PRF and Elmetri, I 1995 Ecological indicators of large-scale eutrophication in the Great Barrier Reef lagoon. Ambio 24(4), 208-215. https://www-jstor-org.ezproxy.slq.qld.gov.au/stable/4314331

7. John, J 2000. Diatom prediction and classification system for urban streams - a model for urban streams. LWRRDC Occasional paper 13/99 (Urban Sub Program, Report No.6) https://nla.gov.au/nla.cat-vn3496458

8. Tomasko, DA and Lapointe, BE 1991 Productivity and biomass of Thalassia testudinum as related to water column nutrient availability and epiphyte levels: field observations and experimental studies. Mar. Ecol. Prog. Ser. 75: 9-17. https://www.intres.com/articles/meps/75/m075p009.pdf

9. Hallegraeff, GM 1993 On the global increase of harmful algal blooms. International workshop on ciguatera management. Bribie Island, Australia https://www.frdc.com.au/Archived-Reports/FRDC\%20Projects/1991-091DLD.pdf

10. Anderson, DM 1995 Toxic red tides and harmful algal blooms: A practical challenge In: Coastal Oceanography. U.S. National report to IUGG. Rev. Geophys., 33, Supplement, pp.45.

https://www.whoi.edu/cms/files/Anderson_1995_GeopRev_HABs_31133.pdf

11. D'Angelo, C and Wiedenmann, J 2014 Impacts of nutrient enrichment on coral reefs: new perspectives and implications for coastal management and reef survival. Curr. Opin. Enviro. Sustain., 7: 82-93. https://doi.org/10.1016/j.cosust.2013.11.029

12. Boyce, DG, Lewis, MR and Worm, B 2010 Global phytoplankton decline over the past century. Nature 466: 591-596. https://doi.org/10.1038/nature09268
13. Anderson, DM, Gilbert, PM and Burkeholder, JM 2002. Harmful algal blooms and eutrophication: Nutrient sources, composition and consequences. Estuaries 25(4b), 704-726. https://doi.org/10.1007/BF02804901

14. Ye, Y, Chen, K and Huo, Y 2019 Long-Term Change of Environment and It's Influence on Phytoplankton Community Structure in Daya Bay. $J$. Coast. Res. 97: 191-197. https://doi.org/10.2112/SI97-027.1

15. ANZECC/ARMCANZ October 2000 Australian and New Zealand Guidelines for Fresh and Marine Water Quality https://www.waterquality.gov.au/sites/default/files/documents/anzeccarmcanz-2000-guidelines-vol1.pdf

16. Masini, RJ, Cary, JL and Simpson, CJ 1995 Light and Posidonia sinuosa seagrass meadows in the temperate coastal waters of Western Australia: III. Minimum light requirements. (Environmental Protection Authority, Perth, Western Australia, 6000). Technical Series 65.

https://www.epa.wa.gov.au/sites/default/files/Policies_and_Guidance/Tech Ser62_DEP_1995.pdf

17. Bellwood, DR, Hoey, AS, Ackerman, JL and Depczynski, M 2006 Coral bleaching, reef fish Community phase shifts and the resilience of coral reefs. Glob. Change Biol., 12: 1587-1594. https://doi.org/10.1111/j.1365-2486.2006.01204.x

18. Cummins, SP, Roberts, DE and Zimmerman, KD 2004 Effects of the green macroalga Enteromorpha intestinalis on macrobenthic and seagrass assemblages in a shallow coastal estuary. Mar. Ecol. Prog. Ser., 266: 7784. https://www.int-res.com/articles/meps2004/266/m266p077.pdf

19. WBM (Winders, Barlow and Morrison Pty. Ltd.) 1990 Preliminary advice - assessment of development constraints at Eli Creek; Hydraulic, coastal and environmental aspects. Prepared for Hervey Bay City Council. Pp. 92.

20. Albert, S, O'Neil, JM, Udy, JW, Ahern, KS, O'Sullivan, CM and Dennison, WC 2005 Blooms of the cyanobacterium Lyngbya majuscule in coastal waters of Queensland, Australia. Mar. Pollut. Bull. 51(1-4): 428437. https://doi.org/10.1016/j.marpolbul.2004.10.016

21. McEwan, J Gabric, AJ and Bell, PRF 1998 Water quality and phytoplankton dynamics in Moreton Bay, south-eastern Queensland. II. Mathematical modelling. Mar. Freshw. Res. 49(3): 227-239. https://doi.org/10.1071/MF97123

22. Zhang, Q, Fisher, TR, Trentacoste, EM, Buchanan, C, Gustafson, AB, Karrh, R, Murphy, RR, Keisman, J, Wu, C, Tian, R, Testa, JM and Tango, JT 2021 Nutrient limitation of phytoplankton in Chesapeake Bay: Development of an empirical approach for water-quality management. Water Res. 188: 1-14. https://doi.org/10.1016/j.watres.2020.116407

23. Roelke, D, Eldridge, PM and Cifuentes, LA 1999 A model of phytoplankton competition for limiting and nonlimiting nutrients: Implications for development of estuarine and nearshore management schemes. Estuaries 22: 92-104. https://doi.org/10.2307/1352930

24. Shah, KA and Joshi, GS 2017 Evaluation of water quality index for River Sabarmati, Gujarat, India. Appl Water Sci., 7: 1349-1358. https://doi.org/10.1007/s13201-015-0318-7

25. Eros, C, Marsh, H, Bonde, R, O’Shea, T, Beck, C, Recchia, C, Dobbs, K, Turner, M, Lemm, S, Pears, R and Bowater, R 2007 Procedures for the Salvage and Necropsy of the Dugong (Dugong dugon) - Second Edition, Research Publication number 8, GBRMPA. Pp 1-104. https://era.daf.qld.gov.au/id/eprint/7842/1/Erosetal20072ndEdDugongNecr opsyManual.pdf

26. Toming, $\mathrm{K}$ and Jaanus, A 2007 Selecting potential summer phytoplankton eutrophication indicator species for the northern Baltic Sea. Proc. Estonian Acad. Sci. Biol. Ecol., 56(4), 297-311. https://kirj.ee/public/Ecology/2007/issue_4/bio-2007-4-7.pdf

27. Hartman, RT and Graffius, JH 1960 Quantitative seasonal changes in the phytoplankton communities of Pymatuning Reservoir, Ecology, 41(2), 333-340. https://www.jstor.org/stable/1930224

28. Underwood, AJ 1997 'Experiments in Ecology: Their Logical Design and Interpretation Using Analysis of Variance', (Cambridge University Press: Cambridge). https://doi.org/10.1017/S0025315400072064

29. Cummins, SP, Roberts, DE, Ajani, P and Underwood, AJ 2004 Comparisons of assemblages of phytoplankton between open water and 
seagrass habitats in a shallow coastal lagoon. Mar. Freshw. Res., 55, 447456. https://doi.org/10.1071/MF04017

30. Clarke, KR and Warwick, RN 2001. Change in Marine Communities: An approach to Statistical Analysis and Interpretation, 2nd edition. Primer-E Ltd: Plymouth. http://www.vliz.be > imisdocs > publications > ocrd

31. Clarke, KR and Gorley, RN 2001. PRIMER v5: Plymouth Routines in Multivariate Ecological Research. User Manual/Tutorial. Primer-E Ltd. 91pp. http://updates.primer-e.com > primer7 > manuals

32. Jacques, G and Sournia, A 1978 LES “EAUX ROUGES” DUES AU PHYTOPLANCTON EN MÉDITERRANÉE. Vie et Milieu , Observatoire Océanologique - Laboratoire Arago, 1978, pp.175- 187. ffhal-02998549 https://hal.sorbonne-universite.fr/hal-02998549

33. Hallegraeff, GM 1994 Species of the diatom genus Pseudonitzschia in Australian waters. Bot. Mar., 37, 397-411. https://doi.org/10.1515/botm.1994.37.5.397

34. Strickland, JDH and Parsons, TR 1972 A practical Handbook of Seawater Analysis. Fish. Res. Board Canada, Bull. 167. https://epic.awi.de/id/eprint/39262/1/Strickland-Parsons_1972.pdf

35. Hasle, GR. Syvertsen, EE, Throndsen, J, Steidinger, KA, Tangen, K and Heimdal, BR 1997. Identifying marine phytoplankton. (C.R. Tomas Ed.). Academic Press, California, USA.

https://www.elsevier.com/books/identifying-marinephytoplankton/tomas/978-0-12-693018-4

36. Hallegraeff, GM 1991 Aquaculturalists' guide to harmful Australian microalgae. CSIRO Division of Fisheries. Print Centre Pty. Ltd. Hobart, Australia.pp. 104. https://www.worldcat.org/title/aquaculturists-guide-toharmful-australian-microalgae/oclc/24560351

37. Stafford, C 1999 Guide to phytoplankton of aquaculture ponds. Dept. of Primary Industries, Queensland. https://nla.gov.au/nla.cat-vn1436183

76. Venrick, EL (1978) How many cells to count? In 'Phytoplankton Manual'. (ed. A. Sournia) pp. 167-180. (UNESCO: Paris). https://www.researchgate.net > publication > links

39. Underwood, AJ 1981 Techniques of analysis of variance in experimental marine biology and ecology. Oceanogr. Mar. Biol., 19, 513-605. https://www.scienceopen.com/document?vid=fffe88ec-4310-4dcf-8fe9$88 \mathrm{f} 1 \mathrm{be} 6 \mathrm{db} 16 \mathrm{c}$

40. Winer, BJ, Brown, DR and Michels, KM 1991 'Statistical principles in Experimental Design.' (McGraw-Hill: New York). https://www.worldcat.org/title/statistical-principles-in-experimentaldesign/oclc/22906883

41. Gell, PA 1997. The development of a database for inferring lake salinity, Western Victoria, Australia: towards a quantitative approach for reconstructing past climates. Aust. J. Bot. 45, 389-423. https://doi.org/10.1071/BT96036

42. Ibelings, W, Admiraal, R, Bijkerk, R, Letswaart, T, and Prins, H 1998. Monitoring algae in Dutch Rivers: does it meet its goals? J. Appl. Phycol., 10, 171-181. https://doi.org/10.1023/A:1008049000764

43. Reid, MA, Tibby JC, Penny, D and Gell PA 1995. The use of diatoms to assess past and present water quality. Austral. Ecology 20(1), 57-64. https://doi.org/10.1111/j.1442-9993.1995.tb00522.x

44. Stevenson, RJ and Pan, Y 1999. Assessing environmental conditions in rivers and streams with diatoms. The Diatoms: Applications for the Earth and Environmental Sciences. EF Stooermer and JP Smol (eds.). Cambridge University Press, New York, 11-40. http://wgbis.ces.iisc.ernet.in/energy/stc/biomonitoring_of_wetlands/diatom lake_river.pdf

45. McEwan, J 2011 Finite Element water quality model for the Moreton Bay system. Coastal Conference, https://www.coastalconference.com/2010/papers2010/Peter_Bell.pdf

46. Chan, TU and Hamilton, DP 2001. Effect of freshwater flow on the succession and biomass of phytoplankton in a seasonal estuary. Mar. Freshw. Res. 52, 869-884. https://doi.org/10.1071/MF00088

47. Nielsen, MV 1996. Growth and chemical composition of the toxic dinoflagellate Gymnodinium galatheanum in relation to irradiance, temperature and salinity. Mar. Ecol. Prog. Ser. 136, 205-211. http://doi.org/10.3354/meps 136205

48. Gobler, CJ, Donat, JR, Consolvo, JA and Sanudo-Wilhlmy, SA 2002. Physicochemical speciation of iron during coastal algal blooms. Mar Chem. 77, 71-89. http://dx.doi.org/10.1016/S0304-4203(01)00076-7
49. Rost, B, Riebesell, U and Burkhardt, S 2003. Carbon acquisition of bloomforming marine phytoplankton. Limnol. Oceanogr. 48(1), 55-67. https://doi.org/10.4319/lo.2003.48.1.0055

50. Bell, P 1992. Eutrophication and coral reefs - some examples in the Great Barrier Reef Lagoon. Water Res., 26(5): 553-568 https://doi.org/10.1016/0043-1354(92)90228-V

51. Bell, PRF, Elmetri, I and Uwins, P 1999 N fixation of Trichodesmium spp. In the Great Barrier Reef Lagoon: Relative importance of the "New" N load. Mar. Ecol. Prog. Ser., 186, 119-126. https://www.jstor.org/stable/24853298

52. Elmetri, I and Bell, PRF 2004 Effects of phosphorous on the growth and nitrogen fixation rates of Lyngbya majuscule: Implications for management in Moreton Bay, Queensland. Mar. Ecol. Prog. Ser., 281, 2735. https://doi.org/10.3354/meps281027

53. Van den Hoek, C, Mann, DG and Jahns, MM 1995. Algae: an introduction to phycology, Cambridge University Press. https://www.worldcat.org/title/algae-an-introduction-tophycology/oclc/444599741

54. Hill, B ., Fraser, IR and Prior, HC 1997. 'Cryptosporidium infection in a dugong (Dugong dugon)'. Aust. Vet. J. 75(9), 670-671. https://doi.org/10.1111/j.1751-0813.1997.tb15369.x

55. Eros C, Marsh H, Bonde R, O'Shea T, Beck C, Recchia C, Dobbs K, Turner M, Lemm S, Pears R and Bowater R 2007 Procedures for the Salvage and Necropsy of the Dugong (Dugong dugon) - Second Edition Publication No. 85, 2007 - era.daf.qld.gov.au https://era.daf.qld.gov.au/id/eprint/7842/1/Erosetal20072ndEdDugongNecr opsyManual.pdf

56. Rose, T 2003 In: Coastal Indicator Knowledge and Information System I: Biophysical Indicators (Radke, L.C., Smith, C.S., Ryan, D.A., Brooke, B., Heggie, D. and contributors). [Frequency of algal blooms] Canberra: Geoscience Australia. accessed 7/11/04. www.ozestuaries.org/indicators/In algal blooms_F.HTML

57. Webster, IT, Parslow, JS, Grayson, RB, Molloy, RP, Andrewartha, J, Sakov, P, Tan, KS, Walker, JS and Wallace, BB 2001 Gippsland Lakes Environmental Study - Assessing options for improving water quality and ecological function. http://www.gcb.vic.au/gippslandlakes/csiro.htm

58. Alpine, AE and Cloern, JE 1992 Trophic interactions and direct physical effects control phytoplankton biomass and production in an estuary. Limnol. Oceanogr., 37; 946-955. https://doi.org/10.4319/lo.1992.37.5.0946

59. Geoscience Australia 2004 Estuaries Database. http://www.ozestuaries.org/frame1.html

60. Connell, JH 1978 Diversity in tropical rainforests and coral reefs. Science, N.Y. 199; 1302-1310. https://www.jstor.org/stable/1745369

61. Huston, M 1979 A general hypothesis of species diversity. Am. Nat., 113; 81-101. https://www.jstor.org/stable/2459944

62. Widdicombe, S and Austen, MC 1998 Experimental evidence for the role of Brissopsis lyrifera (Forbes, 1841) as a critical species in the maintenance of benthic diversity and the modification of sediment chemistry. J. Exp. Mar. Biol. Ecol., 228; 241-255. https://doi.org/10.1016/S0022-0981(98)00032-X

63. Ozestuaries www.ozestuaries.org/indicators now https://ozcoasts.org.au/indicators/

64. Radke, LC, Smith, CS, Ryan DA, Brooke, B, Heggie, D and contributors. 2003 Coastal Indicator Knowledge and Information System I: Biophysical Indicators.[Chlorophyll a Concentrations]. Canberra: Geoscience Australia. www.ozestuaries.org/indicators/In_chlorophyll_a_f.html 


\section{ACKNOWLEDGMENTS}

Peter Bell contributed to the research as a $\mathrm{PhD}$ supervisor to guide all aspects of the experimental design, methodologies, interpretation of results and thesis writing.

Phillipa Uwins and Julie Phillips, John Nailon, Ron Rasch and Bronwyn Cribb are acknowledged for their phytoplankton identification skills and electron microscopy expertise.

Col Maslen contributed to field work with boating, diving and local knowledge. Rachael Hancock, Anya Yago, Gavin Miller and Ruth Grinan assisted with surveys and analyses.

\section{APPENDICES}

Appendix A: Annual means (1993) for water quality parameters.

(top value $=$ mean; bottom value $=$ standard deviation). Sources; $\mathrm{E}: \mathrm{El}$ Creek, P:Pulgul Creek, M:Mary River, B:Burrum River, Be:Beelbi Creek, T:Tuan Creek, K:Kingfisher Bay Resort.

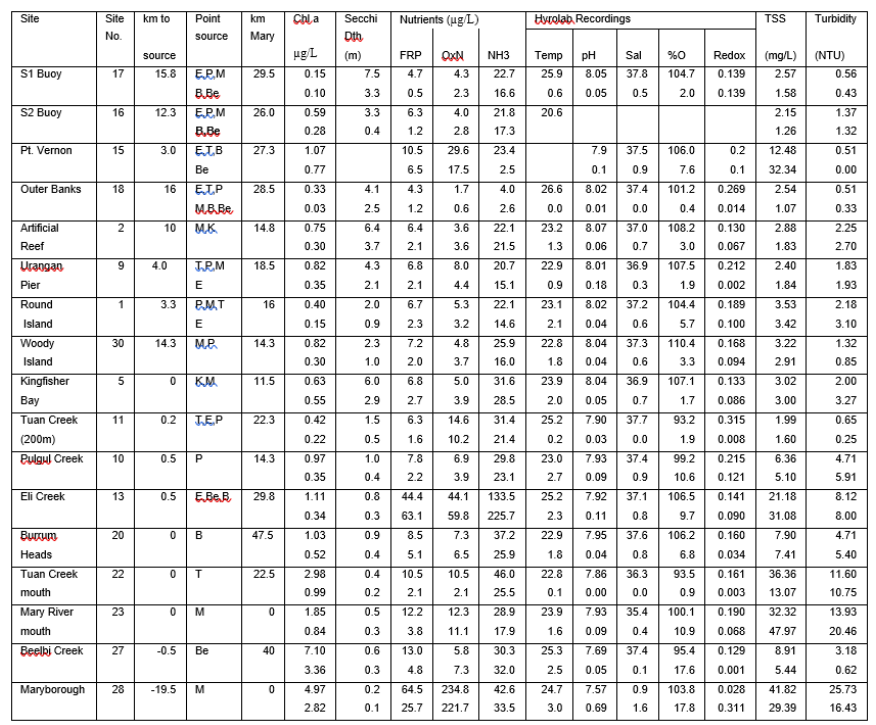

Appendix B: Annual means (1994) for water quality parameters (top value $=$ mean $;$ bottom value $=$ standard deviation )

\begin{tabular}{|c|c|c|c|c|c|c|c|c|c|c|c|c|c|c|c|}
\hline \multirow{2}{*}{$\begin{array}{l}\text { Site } \\
\#\end{array}$} & \multirow{2}{*}{ Name } & \multirow{2}{*}{$\begin{array}{l}\mathrm{km} \text { to } \\
\text { Mary R }\end{array}$} & \multirow{2}{*}{$\begin{array}{l}\text { Chla } \\
\mu \mathrm{g} / \mathrm{L}\end{array}$} & \multirow{2}{*}{$\begin{array}{l}\text { Depth } \\
\text { (m) }\end{array}$} & \multirow{2}{*}{$\begin{array}{l}\text { Secch } \\
i \\
\text { (m) }\end{array}$} & \multicolumn{3}{|c|}{$\begin{array}{l}\text { Soluble Nutrients } \\
(\mu g / \mathrm{L})\end{array}$} & \multirow{2}{*}{$\begin{array}{l}\text { Hydro } \\
\text { Temp }\end{array}$} & \multicolumn{4}{|l|}{ lab } & \multirow{2}{*}{$\begin{array}{l}\text { Tss } \\
\text { mg/L }\end{array}$} & \multirow{2}{*}{$\begin{array}{l}\text { Turb. } \\
\text { NTU }\end{array}$} \\
\hline & & & & & & FRP & NOX & $\mathrm{NH}_{4}$ & & $\mathrm{pH}$ & Sal & \%0x & Redox & & \\
\hline \multirow[t]{2}{*}{2} & Adxticial Reef & 14.8 & 0.63 & 14.5 & 4.9 & 2.8 & 2.0 & 14.4 & 24.1 & 8.06 & 36.9 & 108.5 & 0.211 & 2.03 & 1.3 \\
\hline & & & 0.19 & 2.3 & 1.1 & 1.1 & 2.3 & 13.6 & 3.7 & 0.11 & 0.91 & 3.9 & 0.031 & 0.74 & 0.8 \\
\hline \multirow[t]{2}{*}{5} & Kingfisher & 11.5 & 1.03 & $\begin{array}{ll}16.3 \\
\end{array}$ & 3.8 & 3.3 & 1.0 & 9.4 & 21.8 & 8.04 & 37.1 & $\begin{array}{l}111.7 \\
\end{array}$ & 0.157 & 3.12 & 1.9 \\
\hline & Bay & & 0.37 & 2.9 & 1.1 & 1.2 & 0.0 & 5.2 & 2.7 & 0.41 & 0.57 & 8.2 & 0.089 & 1.01 & 0.9 \\
\hline \multirow[t]{2}{*}{10} & Rulgul $\mathrm{CK}$ & 14.3 & 1.52 & 1.4 & 1.1 & 8.0 & 4.9 & 14.6 & 21.8 & 7.95 & 36.6 & 1042 & 0.140 & 9.96 & 5.7 \\
\hline & & & 1.26 & 0.6 & 0.4 & 6.6 & 5.2 & 13.5 & 3.8 & 0.07 & 1.85 & 8.5 & 0.070 & 8.94 & 5.1 \\
\hline \multirow[t]{2}{*}{16} & S2 Buoy & 26.0 & 0.42 & 9.8 & 5.1 & 3.0 & 1.7 & 12.5 & 23.1 & 8.00 & 37.1 & 108.0 & 0.204 & 1.69 & 1.4 \\
\hline & & & 0.15 & 1.5 & 1.4 & 1.3 & 2.2 & 14.0 & 3.7 & 0.10 & 0.77 & 6.1 & 0.066 & 0.87 & 0.9 \\
\hline \multirow[t]{2}{*}{17} & S1 Buoy & 29.5 & 0.32 & 8.7 & 6.2 & 2.9 & 1.3 & 12.3 & 23.4 & 8.03 & 37.0 & 108.4 & 0.188 & 1.99 & 0.9 \\
\hline & & & 0.26 & 1.2 & 1.8 & 0.9 & 1.0 & 11.0 & 3.6 & 0.11 & 0.66 & 8.6 & 0.030 & 2.41 & 0.5 \\
\hline \multirow[t]{2}{*}{18} & Outer Banks & 28.5 & 0.39 & 18.3 & 6.9 & 3.1 & 4.1 & 23.5 & 23.7 & 8.06 & 36.8 & 106.9 & 0.166 & 249 & 0.8 \\
\hline & & & 0.09 & 4.8 & 1.7 & 2.2 & 5.0 & 20.0 & 3.2 & 0.12 & 0.71 & 14.4 & 0.015 & 2.68 & 0.3 \\
\hline \multirow[t]{2}{*}{30} & Woody Is. & 14.3 & 0.67 & 1.8 & 1.7 & 3.4 & 1.8 & 10.7 & 23.5 & 8.05 & 36.9 & 104.0 & 0.160 & 3.70 & 2.3 \\
\hline & & & 0.33 & 0.7 & 0.7 & 1.1 & 1.7 & 8.2 & 3.5 & 0.33 & 1.30 & 9.5 & 0.039 & 3.28 & 1.3 \\
\hline \multirow[t]{2}{*}{34} & Coongal.Pt. & 33.0 & 0.69 & 2.1 & 20 & 3.0 & 1.4 & 11.7 & 23.7 & 8.04 & 36.8 & 107.1 & 0.170 & 3.61 & 1.4 \\
\hline & & & 0.25 & 0.5 & 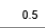 & 1.0 & 1.8 & 7.4 & 3.7 & 0.11 & 0.70 & 6.2 & 0.016 & 2.62 & 0.7 \\
\hline \multirow[t]{2}{*}{35} & Mary River & 3.5 & 1.22 & 6.2 & 2.3 & 6.0 & 4.5 & 9.2 & 24.0 & 7.99 & 35.5 & 106.3 & 0.157 & 6.98 & 3.3 \\
\hline & & & 0.64 & 2.2 & 0.8 & 2.9 & 11.5 & 4.7 & 3.7 & 0.09 & 3.64 & 8.1 & 0.065 & 3.92 & 1.9 \\
\hline
\end{tabular}

Appendix C: Table A Annual N values at each site for 1993 and table B seasonal $N$ values at each site in 1994. $M$ \& $T$; number of meteorological and tidal surveys; nutrient concentrations (SRP, $\mathrm{NO}_{\mathrm{x}}$ $\mathrm{NH}_{4}{ }^{+}$); Scout (submersible probe for temperature, $\mathrm{pH}$, conductivity, oxygen concentration); TSS (mg/L) and turbidity (NTU).

A

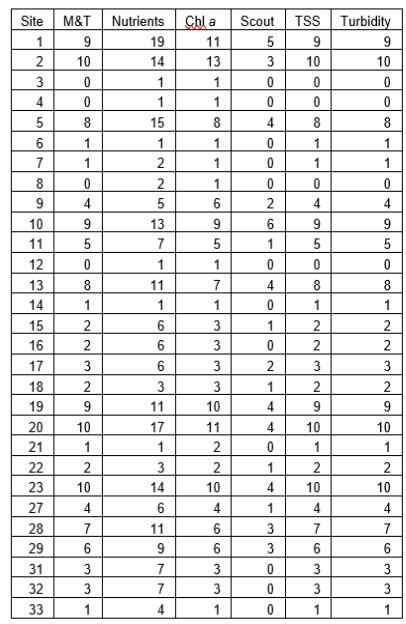

B

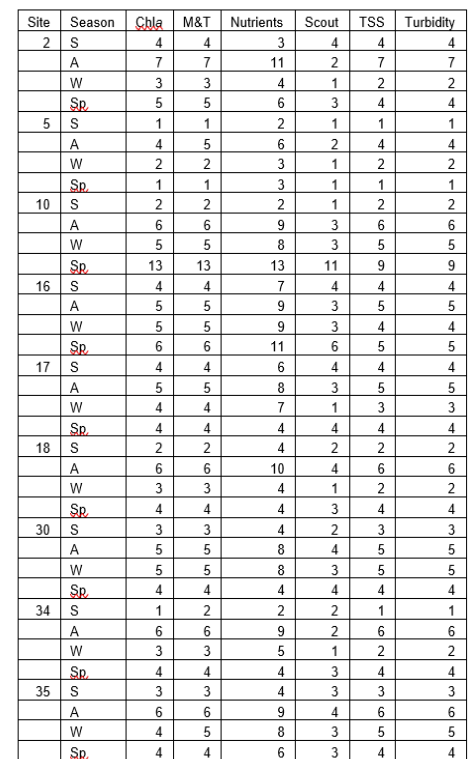

Appendix D: Annual mean and standard deviation values for some water quality parameters for near shore and offshore areas at pilot study sites in 1993 (see Appendix A for sites).
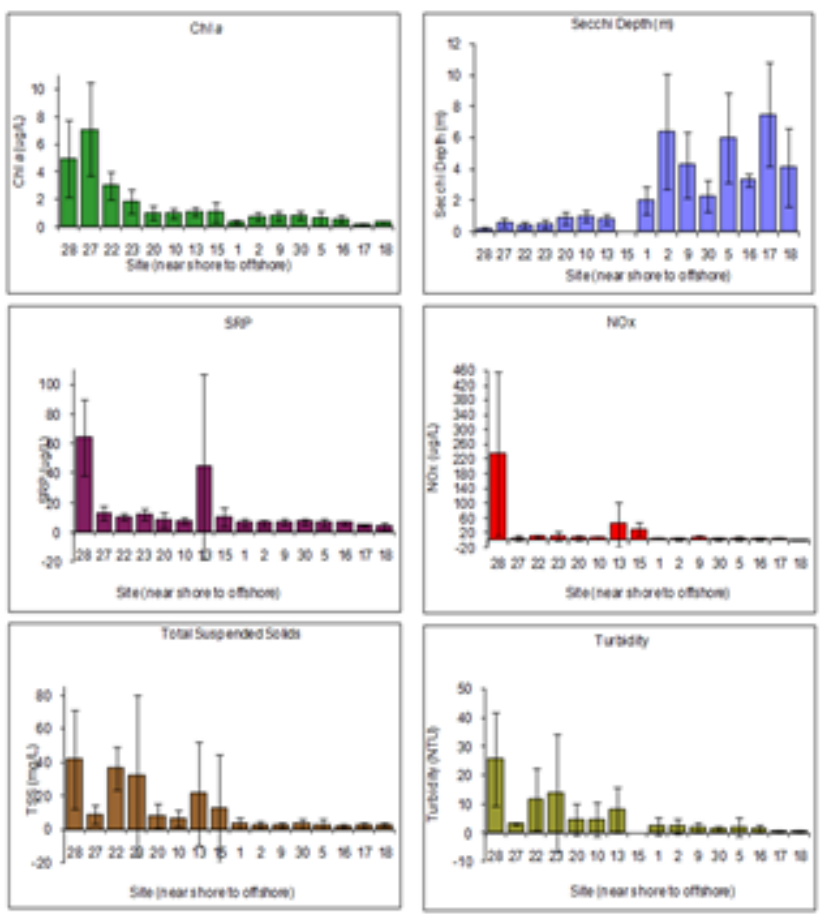
Appendix E: Seasonal means and standard deviations for $\mathrm{Chl} a$, Secchi depth, nutrient concentrations (SRP, $\mathrm{NO}_{x}, \mathrm{NH}_{4}{ }^{+}$), temperature, $\mathrm{pH}$, salinity, oxygen, TSS and turbidity in 1994 in Hervey Bay for the Artificial Reef (site 2), Pulgul Creek (site 10), the S2 Buoy (site 16) and the Mary River mouth (site 35).

\begin{tabular}{|c|c|c|c|c|c|c|c|c|c|c|c|c|}
\hline Season & Site & Cbla & Secchi & SRP & NOx & $\mathrm{NH}_{4+}$ & Temp & $\mathrm{pH}$ & Salinity & Oxygen & TSS & Turbidity \\
\hline \multirow[t]{2}{*}{ Summer } & 2 & 0.67 & 5.88 & 11.88 & 4.38 & 29.13 & 27.55 & 8.17 & 37.30 & 6.94 & 2.04 & 1.10 \\
\hline & & 0.19 & 0.18 & 11.49 & 1.24 & 12.90 & 0.81 & 0.06 & 0.00 & 0.19 & 0.07 & 0.61 \\
\hline \multirow[t]{2}{*}{ Autumn } & & 0.60 & 4.80 & 3.46 & 2.54 & 17.54 & 24.35 & 8.08 & 36.05 & 7.02 & 1.64 & 1.07 \\
\hline & & 0.25 & 1.44 & 0.47 & 1.71 & 5.05 & 4.23 & 0.06 & 0.92 & 0.14 & 0.73 & 0.39 \\
\hline \multirow[t]{2}{*}{ Winter } & & 0.54 & 5.47 & 2.00 & 1.00 & 6.50 & 18.50 & 7.90 & 36.70 & 8.11 & 2.21 & 1.45 \\
\hline & & 0.17 & 0.31 & 1.73 & 0.00 & 0.50 & & & & & 1.11 & 0.10 \\
\hline Spring & & 0.72 & 3.83 & 2.67 & 1.00 & 5.75 & $\begin{array}{r}23.33 \\
2.32\end{array}$ & $\begin{array}{l}7.99 \\
\end{array}$ & $\begin{array}{r}37.30 \\
141\end{array}$ & $\begin{array}{r}7.55 \\
0.27\end{array}$ & 2.44 & 1.83 \\
\hline & & & & & & & & & & & & \\
\hline \multirow[t]{2}{*}{ Summer } & 10 & 2.62 & 1.40 & 5.50 & 3.00 & 19.50 & 26.04 & 8.01 & 38.70 & 6.07 & 12.01 & 4.58 \\
\hline & & 2.89 & & 2.12 & 2.83 & 6.36 & & & & & 14.73 & 5.06 \\
\hline \multirow[t]{2}{*}{ Autumn } & & 1.38 & 0.80 & 7.83 & 7.33 & 22.61 & 23.48 & 7.99 & 34.85 & 7.39 & 11.01 & 5.37 \\
\hline & & 0.56 & 0.44 & 3.25 & 5.03 & 9.06 & 4.34 & 0.12 & 2.47 & 1.09 & 9.22 & 4.01 \\
\hline \multirow[t]{2}{*}{ Winter } & & 0.53 & 1.40 & 10.17 & 2.83 & 9.42 & 17.53 & 7.92 & 36.38 & 7.94 & 1.97 & 1.63 \\
\hline & & 0.05 & 0.17 & 4.86 & 0.76 & 3.11 & 0.58 & 0.07 & 0.04 & 0.89 & 0.71 & 0.31 \\
\hline \multirow[t]{2}{*}{ Spring } & & 1.59 & 1.23 & 6.35 & 3.75 & 11.35 & 23.53 & 7.95 & 37.97 & 6.91 & 14.12 & 7.07 \\
\hline & & 0.63 & 0.21 & 2.94 & 2.46 & 5.53 & 2.68 & 0.05 & 1.16 & 0.55 & 9.13 & 5.16 \\
\hline \multirow[t]{2}{*}{ Summer } & & 0.31 & 6.68 & 10.88 & 14.71 & 52.13 & 27.44 & 8.12 & 37.00 & 6.75 & 1.20 & 0.98 \\
\hline & & 0.05 & 1.66 & 9.37 & 13.14 & 20.33 & 0.84 & 0.06 & 0.21 & 0.57 & 0.26 & 0.55 \\
\hline \multirow[t]{2}{*}{ Autumn } & & 0.39 & 5.81 & 3.25 & 1.75 & 13.83 & 22.95 & 7.99 & 36.35 & 7.10 & 1.28 & 0.91 \\
\hline & & 0.02 & 0.62 & 0.35 & 1.06 & 8.72 & 2.48 & 0.08 & 0.92 & 0.14 & 0.20 & 0.04 \\
\hline \multirow[t]{2}{*}{ Winter } & & 0.35 & 4.80 & 2.67 & 1.00 & 6.17 & 17.55 & 7.93 & 36.80 & 8.11 & 1.38 & 1.19 \\
\hline & & 0.08 & 1.45 & 1.53 & 0.00 & 0.52 & 0.02 & 0.07 & 0.00 & 0.23 & 0.44 & 0.13 \\
\hline \multirow[t]{2}{*}{ Spring } & & 0.61 & 4.58 & 2.75 & 1.00 & 8.17 & 23.05 & 7.96 & 37.55 & 7.39 & 3.07 & 1.97 \\
\hline & & 0.17 & 0.84 & 0.25 & 0.00 & 2.47 & 2.09 & 0.10 & 0.87 & 0.15 & 1.17 & 0.90 \\
\hline \multirow[t]{2}{*}{ Summer } & 35 & 1.50 & 2.25 & 13.88 & 2.38 & 15.88 & 27.55 & 8.12 & 36.83 & 6.60 & 5.90 & 2.33 \\
\hline & & 0.71 & 0.21 & 13.97 & 1.94 & 2.65 & 1.12 & 0.06 & 0.04 & 0.18 & 0.50 & 0.74 \\
\hline \multirow[t]{2}{*}{ Autumn } & & 1.59 & 2.36 & 8.00 & 15.97 & 13.89 & 24.52 & 8.01 & 32.20 & 7.12 & 5.49 & 3.00 \\
\hline & & 1.06 & 0.58 & 5.20 & 25.14 & 4.10 & 2.91 & 0.05 & 6.27 & 0.67 & 3.51 & 1.20 \\
\hline \multirow[t]{2}{*}{ Winter } & & 0.77 & 3.10 & 5.83 & 1.33 & 6.67 & 17.81 & 7.93 & 35.60 & 8.19 & 4.13 & 2.09 \\
\hline & & 0.20 & 0.90 & 1.44 & 0.58 & 0.76 & 0.05 & 0.04 & 0.00 & 0.41 & 2.03 & 0.56 \\
\hline \multirow[t]{2}{*}{ Spring } & & 1.04 & 1.70 & 5.17 & 2.17 & 8.17 & 24.28 & 7.93 & 36.97 & 7.09 & 10.10 & 4.90 \\
\hline & & 0.27 & 0.00 & 0.76 & 1.61 & 3.40 & 2.29 & 0.10 & 1.40 & 0.53 & 4.45 & 1.00 \\
\hline
\end{tabular}

Appendix F: Monthly means and standard deviations for $\mathrm{Chl}$ a, SRP and TSS at the Artificial Reef (site 2), Pulgul Creek (site 10), the S2 Buoy (site 16) and the Mary River mouth (site 35) in 1994.

\begin{tabular}{|c|c|c|c|c|c|c|c|c|c|c|c|c|}
\hline & \multicolumn{3}{|c|}{2} & \multicolumn{3}{|c|}{10} & \multicolumn{3}{|c|}{16} & \multicolumn{3}{|c|}{35} \\
\hline Date & Chl a & SRP & TSS & Cobl a & SRP & TSS & Cobl a & SRP & TSS & Chal a & SRP & TSS \\
\hline \multirow[t]{2}{*}{ January } & 0.54 & 20.00 & 1.99 & * & * & * & 0.34 & 17.50 & 1.38 & 2.00 & 23.75 & 5.54 \\
\hline & 0.04 & 2.83 & 0.27 & & & & 0.08 & 2.12 & 0.23 & 1.45 & 8.13 & 4.32 \\
\hline \multirow[t]{2}{*}{ February } & 0.80 & 3.75 & 2.10 & * & 4.00 & * & 0.28 & 4.25 & 1.02 & 1.00 & 4.00 & 6.25 \\
\hline & 0.57 & 0.35 & 2.36 & & - & & 0.13 & 1.06 & 0.26 & - & - & - \\
\hline \multirow[t]{2}{*}{ March } & 0.52 & 4.00 & 1.20 & 1.25 & 4.50 & 5.56 & * & * & * & 2.80 & 14.00 & 9.48 \\
\hline & - & - & - & - & - & - & & & & - & - & - \\
\hline \multirow[t]{2}{*}{ April } & 0.41 & 3.25 & 1.24 & 2.00 & 8.00 & 21.65 & 0.38 & 3.50 & 1.14 & 0.87 & 5.00 & 2.89 \\
\hline & 0.08 & 0.35 & 0.17 & 1.33 & 1.41 & 23.40 & 0.03 & 0.71 & 0.06 & 0.28 & 0.00 & 1.39 \\
\hline \multirow[t]{2}{*}{ May } & 0.88 & 3.13 & 2.49 & 0.91 & 11.00 & 5.81 & 0.41 & 3.00 & 1.42 & 1.11 & 5.00 & 4.12 \\
\hline & 0.13 & 0.63 & 0.60 & 0.57 & 8.72 & 6.13 & 0.18 & 0.00 & 0.31 & 0.13 & 1.00 & 2.24 \\
\hline \multirow[t]{2}{*}{ June } & 0.72 & 4.00 & 1.42 & 0.59 & 9.00 & 1.39 & 0.45 & 4.00 & 1.19 & 0.53 & 5.00 & 1.79 \\
\hline & - & - & & - & - & & - & - & & - & - & \\
\hline \multirow[t]{2}{*}{ July } & 0.49 & 1.00 & 2.99 & 0.50 & 15.50 & 1.76 & 0.29 & 3.00 & 1.88 & 0.87 & 7.50 & 5.29 \\
\hline & - & - & - & 0.05 & 13.40 & 1.24 & 0.16 & 2.83 & 1.56 & 0.47 & 0.71 & 4.87 \\
\hline \multirow[t]{2}{*}{ August } & 0.40 & 1.00 & $*$ & 0.51 & 6.00 & 2.76 & 0.33 & 1.00 & 1.06 & 0.90 & 5.00 & 5.30 \\
\hline & - & - & & 0.03 & 0.00 & 1.00 & 0.04 & 0.00 & & & 1.41 & 0.51 \\
\hline \multirow[t]{2}{*}{ September } & 0.56 & 1.50 & 1.67 & 0.86 & 8.54 & 7.67 & 0.48 & 2.50 & 2.24 & 0.98 & 5.00 & 6.75 \\
\hline & 0.03 & 0.71 & 0.07 & 0.06 & 8.32 & 1.11 & 0.15 & 0.71 & 0.96 & 0.13 & 2.83 & 3.49 \\
\hline \multirow[t]{2}{*}{ October } & 0.67 & 4.00 & * & 2.00 & 3.00 & $*$ & 0.80 & 3.00 & $*$ & 0.80 & 6.00 & 15.15 \\
\hline & - & - & & - & - & & - & - & & - & - & - \\
\hline \multirow[t]{2}{*}{ November } & 0.93 & 2.50 & 3.21 & 1.90 & 7.50 & 20.58 & 0.56 & 2.75 & 3.90 & 1.34 & 4.50 & 8.39 \\
\hline & 0.18 & 0.71 & 1.18 & 0.15 & 4.95 & 17.60 & 0.27 & 1.06 & 3.26 & & & \\
\hline \multirow[t]{2}{*}{ December } & * & * & * & 4.66 & * & 22.43 & 0.36 & 3.00 & 1.69 & 1.14 & 7.50 & 12.80 \\
\hline & & & & & & & - & - & & - & & \\
\hline
\end{tabular}

Appendix G: Seasonal A Species Richness (S) and B Pielou's Evenness Index (J') for phytoplankton assemblages at near shore (site 35; Mary River mouth, site 10; Pulgul Creek) and offshore zones (site 2; Artificial Reef, site 16; the S2 Buoy) in Hervey Bay in 1994.
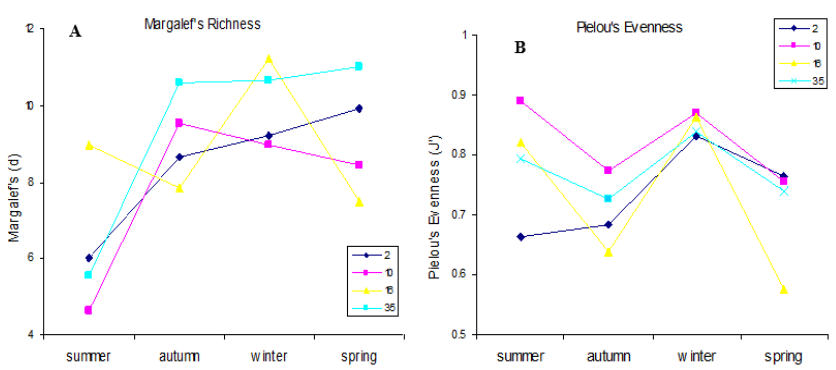

Appendix $\mathrm{H}$ : Mean and standard deviation values for species diversity indices at four locations in Hervey Bay in 1994.

\begin{tabular}{|l|lrrrr|}
\cline { 2 - 6 } \multicolumn{1}{c|}{} & \multicolumn{5}{c|}{ Shannon Diversity } \\
\hline Summer & Site & 2 & 10 & 16 & 35 \\
& Mean & 2.2 & 2.8 & 2.8 & 2.1 \\
& SD & 0.4 & & 0.5 & 0.1 \\
& N & 2 & 1 & 3 & 3 \\
\hline Autumn & Mean & 2.2 & 2.6 & 2.2 & 2.4 \\
& SD & 0.5 & 0.3 & 0.9 & 0.6 \\
& N & 3 & 3 & 2 & 3 \\
\hline Winter & Mean & 2.7 & 2.5 & 2.8 & 2.9 \\
& SD & 0.1 & 0.2 & 0.3 & 0.0 \\
& N & 3 & 3 & 3 & 3 \\
\hline Spring & Mean & 2.6 & 2.3 & 1.7 & 2.5 \\
& SD & 0.7 & 0.1 & 0.7 & 0.5 \\
& N & 3 & 3 & 3 & 3 \\
\hline
\end{tabular}

\begin{tabular}{|l|rrrr|}
\cline { 2 - 5 } Site & \multicolumn{5}{|c|}{ Species Richness } \\
\hline Mean & 2 & 10 & 16 & 35 \\
SD & 18 & 23 & 24 & 17 \\
N & 0 & & 6 & 6 \\
Mean & 2 & 1 & 3 & 3 \\
SD & 22.7 & 26.0 & 26.0 & 29.7 \\
N & 3.2 & 3.0 & 2.8 & 4.9 \\
Mean & 3 & 3 & 2 & 3 \\
SD & 25.0 & 17.3 & 25.0 & 26.3 \\
N & 4.0 & 4.9 & 1.0 & 4.2 \\
Mean & 3 & 3 & 3 & 3 \\
SD & 27.3 & 24.0 & 22.7 & 29.0 \\
N & 4.5 & 2.6 & 3.8 & 2.6 \\
& 3 & 3 & 3 & 3 \\
\hline
\end{tabular}

\begin{tabular}{|l|rrrr|}
\hline \multirow{5}{*}{ Annual } & \multicolumn{3}{|c|}{ Shannon } \\
\hline Site & 2 & 10 & 16 & 35 \\
\cline { 2 - 5 } Mean & 2.42 & 2.50 & 2.40 & 2.47 \\
SD & 0.46 & 0.24 & 0.69 & 0.44 \\
N & 11 & 10 & 11 & 12 \\
$95 \% \mathrm{CI}$ & 0.01 & 0.00 & 0.01 & 0.01 \\
MAX & 3.01 & 2.88 & 3.11 & 2.91 \\
MIN & 1.82 & 2.22 & 1.31 & 1.71 \\
\hline
\end{tabular}

\begin{tabular}{|l|rrrr|}
\hline Annual & \multicolumn{5}{l}{ Species Richness } \\
\hline Site & 2 & 10 & 16 & 35 \\
\cline { 2 - 5 } Mean & 23.7 & 22.5 & 24.4 & 25.4 \\
SD & 4.5 & 4.8 & 3.4 & 6.7 \\
N & 11 & 10 & 11 & 12 \\
95\%CI & 0.09 & 0.09 & 0.06 & 0.12 \\
MAX & 32 & 29 & 30 & 33 \\
MIN & 18 & 14 & 19 & 10 \\
\hline
\end{tabular}

